Review Paper

\title{
Elastic wave velocities as indicators of lithology-based geomechanical behaviour of sedimentary rocks: an overview
}

\author{
Siddharth Garia ${ }^{1}$ Arnab Kumar Pal ${ }^{1}$ - Archana M. Nair ${ }^{1} \cdot$ K. Ravi $^{1}$ (D)
}

Received: 7 May 2020 / Accepted: 5 August 2020 / Published online: 17 August 2020

(c) Springer Nature Switzerland AG 2020

\begin{abstract}
Different geomechanical properties such as elastic modulus/deformation modulus, Poisson's ratio (u), uniaxial compressive strength, shear strength properties, tensile strength and point load index are widely used for rock mass characterisation in geological and geotechnical engineering. However, there are no such direct methods by which these properties can be obtained in the laboratory or in situ, without following time-consuming and a laborious procedure. Thus, ultrasonic technique, an indirect method, was found reliable to determine these properties in rocks. Many researchers have studied the correlation between the compressional wave velocity $(\mathrm{Vp})$ and the geomechanical properties of sedimentary rocks such as sandstones and carbonates. However, these correlations have not considered the change in rock mineralogy, porosity and saturation conditions when deriving relationships. Hence, in this study, the authors attempt to understand the variability of $\mathrm{V} p$ with the help of a fragmented analysis of major mineral constituents, porosity variation and saturation conditions for rock mass classification based on $\mathrm{Vp}$. A review of the existing studies on the relationship between the rock properties and $V p$ has been used to perform this analysis. The resulting template can be a basis for interpreting more realistic lithology-based geomechanical behaviours and thus highlights the importance of an integrated study involving geological, petrophysical and engineering data. The results derived from fragmented analysis indicate that with an increase in quartz content and a subsequent decrease in feldspar content in sandstones, Young's modulus $(E)$ and $V p$ increase. With an increase in porosity from 2 to $40 \%$, there is a decrease in $E$ and $V p$ values for all types of saturation scenarios (water, gas, brine and oil saturated) for sandstones and carbonates.
\end{abstract}

Keywords Compressional wave $\cdot$ Velocity $\cdot$ Ultrasonic $\cdot$ Elastic modulus

$\begin{array}{ll}\text { List of symbols } \\ A & \text { Area of specimen } \\ C & \text { Clay content (\%) } \\ D_{\mathrm{e}} & \text { Effective diameter } \\ E & \text { Elastic modulus (GPa) } \\ G & \text { Shear modulus (GPa) } \\ I_{\mathrm{s}} & \text { Point load strength (MPa) } \\ K & \text { Bulk modulus (GPa) } \\ L & \text { Length of specimen } \\ n & \text { Porosity (\%) } \\ P & \text { Breaking load }\end{array}$

Electronic supplementary material The online version of this article (https://doi.org/10.1007/s42452-020-03300-1) contains supplementary material, which is available to authorized users.

$\begin{array}{ll}\text { SDI } & \text { Slake durability (\%) } \\ S_{\mathrm{r}} & \text { Degree of saturation (\%) } \\ t & \text { Transit time } \\ \text { UCS } & \text { Unconfined compressive strength }(\mathrm{MPa}) \\ V & \text { Loss of volume on wear }\left(\mathrm{cm}^{3} / 50 \mathrm{~cm}^{2}\right) \\ V p & \text { P-wave velocity }(\mathrm{km} / \mathrm{s}) \\ V s & \text { S-wave velocity }(\mathrm{km} / \mathrm{s}) \\ \tau & \text { Shear strength }(\mathrm{MPa}) \\ U & \text { Poisson's ratio } \\ \chi & \text { Lame's parameter } \\ \sigma_{\mathrm{t}} & \text { Indirect tensile strength }(\mathrm{MPa})\end{array}$

K. Ravi, ravi.civil@iitg.ac.in | 'Department of Civil Engineering, Indian Institute of Technology, Guwahati 781039, India. 


\section{Introduction}

Most of the engineering projects related to rocks such as petroleum reservoir geomechanics, foundation and slopes, civil and mining require the knowledge of the subsurface properties during the initial phase of any exploration activity. The behaviour of a rock mass in response to a specific loading system is influenced by its mechanical and the strength properties. However, the present set of established correlations do not consider the change in rock mineralogy, porosity and saturation conditions. The factors such as lithology, density, porosity, permeability, clay volume, bedding planes, weathering, porewater, anisotropy, grain size, mineralogy and saturation play an influential role in affecting the geomechanical properties of rocks [8, 21, 70, 83]. The geomechanical properties such as elastic modulus/ deformation modulus, Poisson's ratio (u), uniaxial compressive strength (UCS), shear strength properties, tensile strength, point load index and rock hardness play a decisive role while assessing stability criteria for studies related to geotechnical problems that involve civil, mining, slope stability, underground excavations, oil recovery, nuclear waste disposal and well bore instabilities during drilling $[11,52]$. The rock strength is a crucial geomechanical property, and it is categorised as compressive (UCS) and tensile. The rock's bearing capacity may be indicative by the UCS value of rock, and elastic modulus and Poisson's ratio can be estimated from UCS [80]. Tensile strength is indicative of the resistance of failure of the rock mass, and it is imperative when dealing with stability of underground openings [65]. Modulus of elasticity $(E)$ can be used for intact rock classification and rock failure criteria. Among the elastic properties, Poisson's ratio $(u)$ plays a fundamental role in the elastic deformation of rocks and rock masses subjected to static/dynamic stresses [26]. The slake durability test estimates the resistance of rock samples to weakening and breakdown resulting from a standard cycle of wetting and drying [70, 72]. Point load strength is also a measure for the determination of rock strength. Point load test is an alternate method to estimate UCS since it is a reliable, economical and easy technique [52]. The conventional tests used for determining the geomechanical properties in laboratory involve rigorous, time-consuming and destructive tests [45]. Moreover, these procedures are expensive which involve the requirement of specimens to be precisely, carefully prepared (following the specifications that are laid as per standards). There are no such direct methods by which these properties can be obtained in the laboratory or in situ, without following time-consuming and a laborious procedure [47].
The difficulty mostly arises due to the sampling issues encountered during the boundary strength conditions of a weak rock [61]. These difficulties motivated researchers to develop non-destructive techniques so as to predict strength and deformability properties which can be measured from relatively easier and reliable techniques such as ultrasonic methods [45].

The application/usage of compressional wave velocity, also known as Vp or p-wave (primary wave), is a common non-destructive method for rock mass characterisation in laboratory and on-site $[69,81]$. The elastic wave velocity such as Vp provides a comprehensive index for determining the petrophysical and mechanical properties of rock [12]. The elastic waves can be reproduced in the laboratory with the help of ultrasonic techniques $[45,66]$. In other words, in comparison with the mechanical tests, ultrasonic techniques are simple to use, rapid to analyse and more economical than any other technique $[27,44]$. As a result, to determine the quality of rock without destructing the rock, ultrasonic techniques are widely used in geotechnical, rock science and mining practices [48]. Researchers have obtained a strong correlation between geomechanical properties (UCS, indirect tensile strength, E, U, slake durability, point load strength) and Vp, Vs (longitudinal and shear wave) for different rocks (sandstone, shale, limestone, coal, marlstone, siltstone, conglomerate, marl, dolomitic limestone, dolomite, argillaceous limestone, claystone). Table 1 presents the summary of techniques used by various researchers on different rocks reported in the literature. Different empirical relations have also been reported in the literature correlating these geomechanical properties with Vp, Vs for different rock types. These correlations were achieved based on numerous testing from different types of formations with different lithology and different parts of the world (Fig. 1). The use of such empirical correlations is sometimes the only method to evaluate the strength under certain conditions where rock cores cannot be obtained for conducting laboratory tests. However, the relationship between the geomechanical properties and $V p$, Vs also depends on some influential factors such as grain size and shape, rock type, rock texture and structure, mineralogical composition, density, porosity, temperature, porewater, anisotropy, weathering, confining pressure, joint properties, alteration zones and bedding planes [83]. Some of these factors such as mineralogy, saturation conditions and porosity effects have been considered in this study for the estimation of lithology-based geomechanical behaviour on the basis of $\mathrm{Vp}$.

This paper discusses the lithology-based assessment of geomechanical properties of sedimentary rocks on the basis of $\mathrm{Vp}$ and hence provides a methodology for future-based similar studies. Initially, the paper collates the research conducted by different researchers on $\mathrm{Vp}$ and its relation with 
Table 1 Summarised data details reported in the literature

\begin{tabular}{|c|c|c|c|c|}
\hline \multicolumn{2}{|c|}{ Designation } & \multirow{2}{*}{$\begin{array}{l}\text { Rock type } \\
\text { Limestone, mudstones, psammite, } \\
\text { greenstones, granites }\end{array}$} & \multirow{2}{*}{$\begin{array}{l}\text { Laboratory technique } \\
\text { used } \\
-\end{array}$} & \multirow{2}{*}{$\begin{array}{l}\text { References } \\
\text { D'Andrea et al. [15] and } \\
\text { extended by McCann } \\
\text { et al. [54] }\end{array}$} \\
\hline$A$ & A & & & \\
\hline$B$ & B & Sandstone & - & Freyburg [23] \\
\hline $\mathrm{C}$ & $\mathrm{C}$ & Sandstone & - & Fjaer [22] \\
\hline $\mathrm{D}$ & $\mathrm{D}$ & Sandstone & $\begin{array}{l}\text { Through transmission, } \\
\text { P-wave frequency } 1 \mathrm{MHz} \\
\text { and } \mathrm{S} \text { wave } 0.6 \mathrm{MHz}, \mathrm{V}_{\mathrm{p}} \\
\text { measured on water-sat- } \\
\text { urated rocks at different } \\
\text { confining pressures (up } \\
\text { to } 40 \mathrm{MPa} \text { ) }\end{array}$ & Han et al. [28] \\
\hline$E$ & $\mathrm{E}$ & Sandstone & - & Moos et al. [58] \\
\hline $\mathrm{F}$ & $\mathrm{F}$ & Limestone & $\begin{array}{l}\text { Through transmission, } \\
\text { transducer frequency } \\
54 \mathrm{kHz}\end{array}$ & Kahraman [42] \\
\hline G & G & Carbonates & Through transmission & Yasar and Erdogan [83] \\
\hline \multirow[t]{4}{*}{$\mathrm{H}$} & $\mathrm{H} 1$ & Sandstone & Not mentioned & Chang et al. [11] \\
\hline & $\mathrm{H} 2$ & Shale & & \\
\hline & $\mathrm{H} 3$ & Limestone & & \\
\hline & $\mathrm{H} 4$ & Dolomite & & \\
\hline \multirow[t]{2}{*}{ I } & 11 & Limestone & Through transmission & Kilic and Teymen [48] \\
\hline & 12 & Sandstone & & \\
\hline \multirow[t]{2}{*}{$J$} & $\mathrm{~J} 1$ & Limestone & Not mentioned & Çobanoglu and Çelik [14] \\
\hline & $J 2$ & Sandstone & & \\
\hline $\mathrm{L}$ & $\mathrm{L}$ & Carbonate rocks & $\begin{array}{l}\text { Through transmission } \\
\text { transducer frequency } \\
54 \mathrm{kHz}\end{array}$ & Kahraman and Yeken [44] \\
\hline \multirow[t]{3}{*}{ M } & M1 & Sandstone & Through transmission & Sharma and Singh [70] \\
\hline & $\mathrm{M} 2$ & Coal & & \\
\hline & M2 & Shaly rock & & \\
\hline \multirow[t]{3}{*}{$\mathrm{N}$} & $\mathrm{N} 1$ & Limestone & \multirow{3}{*}{$\begin{array}{l}\text { Through transmission, } \\
\text { transducer frequency } \\
1 \mathrm{MHz}\end{array}$} & Moradian and Behnia [59] \\
\hline & $\mathrm{N} 2$ & Sandstone & & \\
\hline & N3 & Marlstone & & \\
\hline \multirow[t]{5}{*}{$\mathrm{O}$} & 01 & Sandstone & Ultrasonic pulse technique & Soroush et al. [73] \\
\hline & $\mathrm{O} 2$ & Siltstone & & \\
\hline & $\mathrm{O} 3$ & Conglomerate & & \\
\hline & $\mathrm{O} 4$ & Limestone & & \\
\hline & O5 & Marl & & \\
\hline \multirow[t]{6}{*}{$\mathrm{P}$} & P1 & Limestone & Through transmission & Sarkar et al. [66] \\
\hline & P2 & Sandstone & & \\
\hline & P3 & Dolomitic limestone & & \\
\hline & P4 & Dolomite & & \\
\hline & P5 & Coal & & \\
\hline & P6 & Shale & & \\
\hline \multirow[t]{6}{*}{ Q } & Q1 & Marl & Through transmission & Karakul and Ulusay [45] \\
\hline & Q2 & Sandstone & & \\
\hline & Q3 & Argillaceous limestone & & \\
\hline & Q4 & Limestone & & \\
\hline & Q5 & Sandstone & & \\
\hline & Q6 & Clay stone & & \\
\hline
\end{tabular}


Table 1 (continued)

\begin{tabular}{|c|c|c|c|c|}
\hline \multicolumn{2}{|c|}{ Designation } & \multirow{2}{*}{$\begin{array}{l}\text { Rock type } \\
\text { Limestone }\end{array}$} & \multirow{2}{*}{$\begin{array}{l}\text { Laboratory technique } \\
\text { used }\end{array}$} & \multirow{2}{*}{$\begin{array}{l}\text { References } \\
\text { Parent et al. [64] }\end{array}$} \\
\hline $\mathrm{R}$ & $\mathrm{R}$ & & & \\
\hline $\mathrm{S}$ & $\mathrm{T}$ & Dolostone & $\begin{array}{l}\text { High-emission MAE device } \\
\text { with probes of frequency } \\
53 \mathrm{kHz}\end{array}$ & Pappalardo [63] \\
\hline $\mathrm{T}$ & $\mathrm{T}$ & Limestone & $\begin{array}{l}\text { Ultrasonic pulse generator } \\
\text { operating at } 54 \mathrm{kHz}\end{array}$ & Kurtulus et al. [51] \\
\hline$U$ & $\mathrm{U}$ & Carbonate rocks & Through transmission & Madhubabu et al. [52] \\
\hline
\end{tabular}

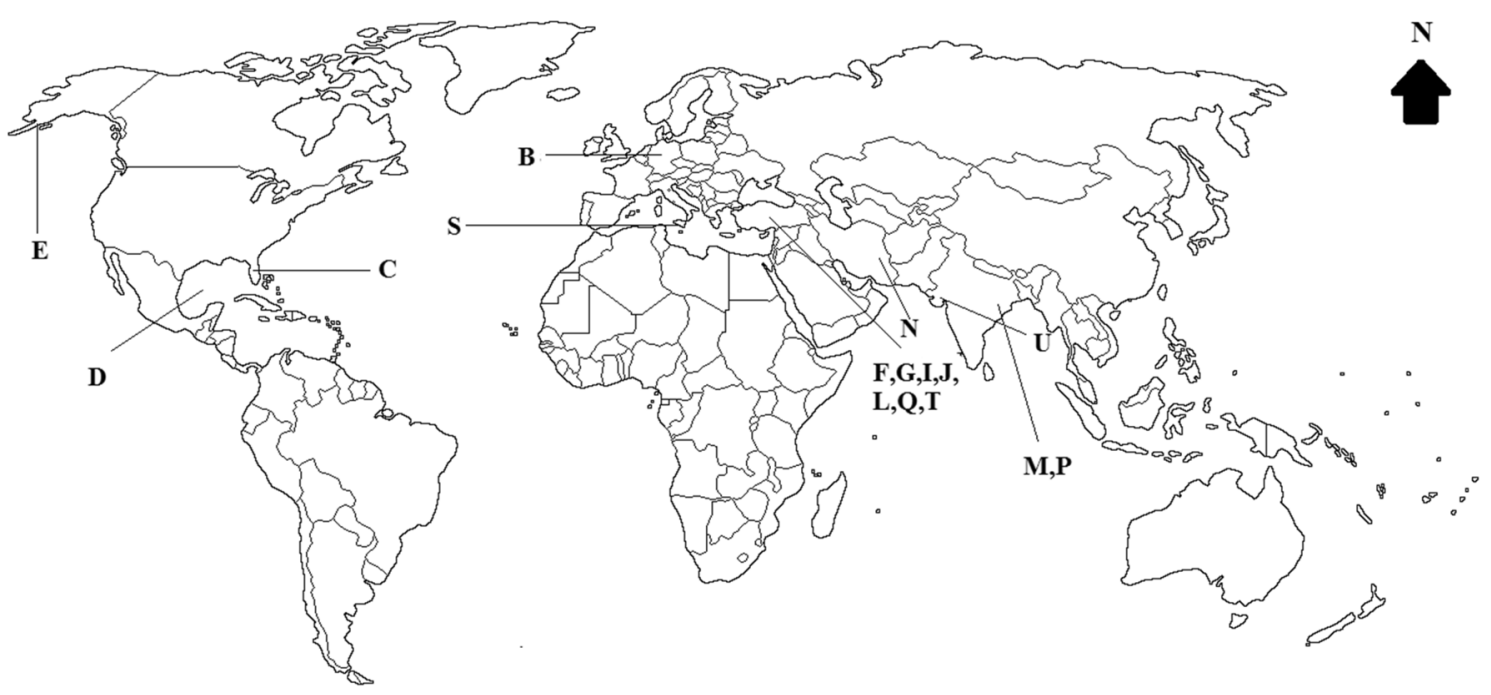

Fig. 1 Location map of different sedimentary rock samples reported in this study. Legends: B-Thuringia, Germany, C-Gulf Coast, USA, D-Gulf of Mexico, E-Cook Inlet, Alaska, USA, F-Turkey, G-Adana, Turkey, I-Southern Anatolia, Turkey, J-Turkey, L-Nigde, Kayseri, Konya and Antalya, Turkey, M-Lower Shiwalik and Lower

the geomechanical properties of rocks. These relations may be used when it is difficult to obtain cores from weak, highly fractured and weathered rocks. Such indirect estimation, however, leads to an over- or underestimation of test results when correlated without taking into the consideration the lithology, saturation conditions and mineralogy. Thus, the later part of the paper inculcates the variability of major mineral constituents, saturation conditions and porosity on the geomechanical properties of sedimentary rocks. Such a fragmented analysis would help to demonstrate the benefits of lithology-based geomechanical behaviour/classification on the basis of $\mathrm{Vp}$. The conclusions provide a summary of the state of play that should be understood by the users of this type of data. Vp and Vs are indicators of geomechanical behaviour, and it is important to stress that it is all they are. It is important to understand the mineralogy, density and porosity in order to avoid time and costs of running into unexpected problems during any underground excavations,
Gondwana (Singrauli and Jharia), India, N-Iran, P-Jutogh, Lower Shiwalik and Lower Gondwana, India, Q-Turkey, S-Peloritani Mounts, NE Sicily, T-Cebecikoy, Hereke, Akveren, Soguck and Bakirkoy, Turkey, U-Kutch, Gujrat, India

oil recovery, nuclear waste disposal and well bore instabilities during drilling.

\section{Applied methodology}

\subsection{Compilation of the dataset}

$V p$, Vs have been correlated with different mechanical properties from dataset available in the literature to understand the existing association between the two and its importance in reservoir characterisation. The datasets in this review are based on mainly sandstones and carbonate rocks under ambient conditions. Moreover, the datasets considering confining pressure have not been considered in this review. This study was conducted by using literature datasets generated from experimental measurements under ambient conditions in order to have 
Table 2 Instruments/tests used/conducted in the literature

\begin{tabular}{ll}
\hline Parameter analysis & Instrument/test \\
\hline Vp and Vs & UPV meter \\
UCS & UCS test \\
Indirect tensile strength & Brazilian tensile strength test \\
Durability & Slake durability test \\
Mineralogy & XRD, thin-section studies \\
\hline
\end{tabular}

Table 3 Standards for determination of different parameters of rocks

\begin{tabular}{ll}
\hline Parameter & Standard \\
\hline P-wave velocity $\left(V_{p}\right)$ & ASTM D2845, IS 13311 Part 1:1992 \\
Point load index & ASTM D5731, IS 8764-1998 \\
UCS & IS 9143-1979, ASTM D2938-2002 \\
Brazilian tensile strength & IS 10082-1981, ASTM D3967-08 \\
Durability (slake durability) & IS 10050-1981 \\
\hline
\end{tabular}

a common reference condition. Other datasets reported at confining pressures in the literature $[28,50,74]$ were found to be derived under different stress values rather than a common standard value. Hence, it will be challenging to establish a common reference condition to correlate $\mathrm{Vp}$ with the different geomechanical parameters. In order to allow experimental results to be extrapolated to natural conditions at a depth $z$, such a study [38] may be referred when temperature and pore pressure effects also need to be considered. The datasets have been plotted together, and graphs of variation of compressional wave velocity with UCS, $\sigma_{\mathrm{t}}, E, U$, slake durability and point load strength have been shown. Table 2 highlights the instruments/tests used/conducted by researchers for their study to generate the datasets. Due to scarcity of available data, the rocks considered in this review, namely sandstones and carbonate rocks are neither from any particular geological time period nor any preference of a geographical region has been taken. The map (Fig. 1) shows the locations of the rock types considered, and it illustrates all the available datasets from the entire world have been considered for this literature review. It was seen that datasets for the measured shear wave velocity (Vs), available from experiments, were rare, while relating Vs and geomechanical properties of rocks. One of the reasons for this may be calculation of Vs from Vp values, based on methods, suggested by earlier researchers [9]. The foundation of those methods is several empirical relations, such as $\mathrm{Vp} / \mathrm{Vs}=1.65-2$ [41], $\mathrm{Vp} / \mathrm{Vs}=1.5-1.7$ for quartzose sandstones and $\mathrm{Vp} / \mathrm{Vs}=1.9$ for pure limestones [1]. Therefore, by using these correlations, the relationship between Vs and geomechanical properties can be assessed. Moreover, the datasets reported in the manuscript belong to tests conducted on dry rocks. Furthermore, to measure Vp, Vs in laboratory, researchers have used different ultrasonic techniques: through transmission and pulse-echo for different rock samples $[10,24,25,40,43,46]$. The $V p$, Vs values in the rock samples can be measured either by using a pulse generator unit, a pair of transducers (one acting as a transmitter and the other one as a receiver) of frequencies varying generally from $54 \mathrm{kHz}$ to $1 \mathrm{MHz}$, along with an oscilloscope $[60,76]$ or by using portable ultrasonic non-destructive digital indicating tester, widely known as PUNDIT [55]. The literature reference regarding laboratory technique used by different researchers is summarised in Table 1. Two different types of transducers: a longitudinal (P-wave) transducer for measuring $V p$ and a shear (S-wave) transducer for measuring Vs, have been used. The test procedures for determining $V p$, point load index, UCS and E have been standardised by ISRM [29, 31, 32] and ASTM [2-4] (Table 3). Table 3 summarises the standards for determination of different parameters of rocks by following a given set of protocols/specifications that are followed worldwide. As per recommendations [30], the minimum lateral dimension must not be less than ten times the wavelength. If the wavelength is considerably greater than the grain size, then the measured velocity is not frequency dependent [30].

\subsection{Fragmented analysis of major mineral constituents and saturation conditions for rock mass classification based on $\mathrm{Vp}$}

Since there are multiple parameters that alter the elastic and mechanical properties of sedimentary rocks, an attempt is made to introduce and then analyse its variability with some of the mechanical properties. Since rock is composed of multiple minerals, varying the amount of these major minerals would reflect the change in $V p$, and this change in Vp could thereby be related to get an inference on a certain property under investigation. For instance, in sandstones, the major minerals present include quartz and feldspar, while for carbonates, the major minerals present include calcite and dolomite. These minerals have certain parameter values such as $V p_{\text {quartz }}=6.057 \mathrm{~km} / \mathrm{s}, V p_{\text {feldspar }}=4.68 \mathrm{~km} / \mathrm{s}$, $V p_{\text {calcite }}=6.259 \mathrm{~km} / \mathrm{s}$ and $V p_{\text {dolomite }}=6.93 \mathrm{~km} / \mathrm{s}[16,53,62$, 71]. These values are the maximum, i.e. for zero porosity. Vp of feldspar is taken as $4.68 \mathrm{~km} / \mathrm{s}$ ("average" feldspar [53]). However, based on composition of feldspar, values may vary. Similarly, the other parameter values such as Vs, density, $U, K, G$ and $E$ for these minerals are given in Table 4 .

For changing $V p$, the density of material was varied by changing the mineralogy of the rock as well as the 
Table 4 Different parameter values for different minerals (these values are the maximum (zero porosity)) $[16,53,62,71]$

\begin{tabular}{|c|c|c|c|c|c|c|c|}
\hline Minerals & $\mathrm{Vp}(\mathrm{km} / \mathrm{s})$ & Vs $(\mathrm{km} / \mathrm{s})$ & Density (g/cc) & Poisson's ratio & $\begin{array}{l}\text { Bulk modulus } K \\
(\mathrm{GPa})\end{array}$ & $\begin{array}{l}\text { Shear modulus } \\
G(\mathrm{GPa})\end{array}$ & $\begin{array}{l}\text { Young's } \\
\text { modulus } E \\
(\mathrm{GPa})\end{array}$ \\
\hline Quartz & 6.057 & 4.153 & 2.65 & 0.08 & 37 & 44 & 95 \\
\hline Calcite & 6.259 & 3.243 & 2.71 & 0.316 & 76.8 & 32 & 84.2 \\
\hline Dolomite & 6.93 & 4.23 & 2.87 & 0.202 & 76.4 & 49.7 & 119.4 \\
\hline $\begin{array}{l}\text { Feldspar } \\
\text { Vp variatiol }\end{array}$ & 4.68 & 2.39 & 2.56 & 0.32 & 37.5 & 15 & 39.6 \\
\hline Vp order & Mineralogy & \multicolumn{6}{|c|}{ Dolomite $>$ calcite $>$ quartz $>$ feldspar } \\
\hline Vp order & Fluids & \multicolumn{6}{|c|}{ Brine $>$ water $>$ oil $>$ gas } \\
\hline
\end{tabular}

Table 5 Tabulated datasets of Poisson's ratio and Vp obtained by varying the volume percentage of major minerals for sandstones and carbonates

\begin{tabular}{|c|c|c|c|c|c|c|c|}
\hline \multicolumn{4}{|l|}{ Sandstones } & \multicolumn{4}{|l|}{ Carbonates } \\
\hline $\begin{array}{l}\text { Fraction of } \\
\text { quartz }\end{array}$ & $\begin{array}{l}\text { Fraction of } \\
\text { feldspar }\end{array}$ & $\mathrm{Vp}\left(=\mathrm{V} \mathrm{p}_{\text {matrix }}\right)$ & Poisson's ratio $(u)$ & $\begin{array}{l}\text { Fraction of } \\
\text { calcite }\end{array}$ & $\begin{array}{l}\text { Fraction of } \\
\text { dolomite }\end{array}$ & $\mathrm{Vp}\left(=\mathrm{V} \mathrm{p}_{\text {matrix }}\right)$ & Poisson's ratio $(u)$ \\
\hline 0.75 & 0.25 & 5.71275 & 0.14 & 0.75 & 0.25 & 6.42675 & 0.2875 \\
\hline 0.8 & 0.2 & 5.7816 & 0.128 & 0.8 & 0.2 & 6.3932 & 0.2932 \\
\hline 0.85 & 0.15 & 5.85045 & 0.116 & 0.85 & 0.15 & 6.35965 & 0.2989 \\
\hline 0.9 & 0.1 & 5.9193 & 0.104 & 0.9 & 0.1 & 6.3261 & 0.3046 \\
\hline 0.95 & 0.05 & 5.98815 & 0.092 & 0.95 & 0.05 & 6.29255 & 0.3103 \\
\hline 1 & 0 & 6.057 & 0.08 & 1 & 0 & 6.259 & 0.316 \\
\hline
\end{tabular}

saturation of pores. Thus, we assume several volume percentages of these minerals so as to change the density of the material. For sandstones, the volume percentage was varied from $75 \%$ quartz and $25 \%$ feldspar to $100 \%$ quartz and $0 \%$ feldspar content. Similarly, for carbonates, volume percentage was varied from $75 \%$ calcite and $25 \%$ dolomite to $100 \%$ calcite and $0 \%$ dolomite content. Based on these varying volume mineral percentages, $\mathrm{Vp}$ was calculated as:

$\left(\mathrm{V}_{\text {Quartz }}\right) \times\left(\mathrm{V}_{\text {Quartz }}\right)+\left(\mathrm{V}_{\text {Feldspar }}\right) \times\left(\mathrm{Vp}_{\text {Feldspar }}\right)=\mathrm{Vp}$

$\left(\mathrm{V}_{\text {Calcite }}\right) \times\left(\mathrm{V}_{\text {Calcite }}\right)+\left(\mathrm{V}_{\text {Dolomite }}\right) \times\left(\mathrm{V}_{\text {Dolomite }}\right)=\mathrm{Vp}$

where $\mathrm{V}_{\text {Quartz }}, \mathrm{V}_{\text {Feldspar }}, \mathrm{V}_{\text {Calcite }}$ and $\mathrm{V}_{\text {Dolomite }}$ are the volume percentages (in fraction) of these minerals.

These equations are based on the Voigt averaging (isostrain conditions) [5] which may overestimate the velocities of the mixtures. At any given volume fraction of constituents, $\mathrm{Vp}$ will fall between the bounds but its precise value depends on the geometric details. Since the geometric details of the datasets in the literature are not known, an allowable theoretical range of seismic velocity values or the upper bound values were computed by using Voigt averaging method. Other methods like Voigt-Reuss-Hill average can also be used. Moreover,
Table 6 Compressional wave velocity and bulk moduli values for some fluids [68]

\begin{tabular}{lll}
\hline Fluids & $\mathrm{Vp}(\mathrm{km} / \mathrm{s})$ & $\begin{array}{l}\text { Bulk modu- } \\
\text { lus K (GPa) }\end{array}$ \\
\hline Brine & 1.635 & 2.6 \\
Water & 1.5 & 2.2 \\
Oil & 1.2 & 1.1 \\
Gas & 0.6 & 0.1 \\
\hline
\end{tabular}

various studies $[33,37,39]$ may be referred to estimate the different parameters based on phenomenological approach.

The tabulated datasets of $\mathrm{Vp}$ obtained by varying the volume percentage of major minerals for sandstones and carbonates are presented in Table 5. Doing such an exercise would provide the range of $\mathrm{Vp}$ values for different proportions of quartz and feldspar content for sandstones, calcite and dolomite content for carbonates, which would help in understanding the variability of major minerals with $\mathrm{Vp}$. The common aim is to construct a template that honours the data (known data) and extends the interpretation to unknown situations, in different exploration cases. Table 6 shows Vp and bulk moduli values for some fluids [68]. 
In order to forecast the effective elastic moduli of a mixture of grains and pores, Hashin-Shtrikman-Walpole bounds $[5,77]$ were used for evaluating bulk and shear moduli ( $K$ and $G$, refer Eqs. 3, 4, 5 and 6 ). Thereafter, $E$ was calculated by using Eq. 10. The range of datasets of $E$ and $V p$ obtained by varying the volume percentage of major minerals for sandstones and carbonates, with a porosity variation from 2 to $40 \%$ for different geological scenarios (fluid saturations-water, gas, brine and oil), is provided in supplementary information (Table S1). The formulation of Hashin-Shtrikman-Walpole bounds [5] is presented in the form of equations:

$K^{\mathrm{HS}+}=\wedge\left(G_{\max }\right)$,

$K^{\mathrm{HS}-}=\wedge\left(G_{\max }\right)$

$G^{\mathrm{HS}+}=\Gamma\left(£\left(K_{\max }, G_{\max }\right)\right)$

$G^{\mathrm{HS}-}=\Gamma\left(£\left(K_{\min }, G_{\min }\right)\right)$

where

$\wedge(z)=\left\{\frac{1}{K(r)+\frac{4}{3} z}\right\}^{-1}-\frac{4}{3} z$

$\Gamma(z)=\left\{\frac{1}{G(r)+z}\right\}^{-1}-z$

$£(K, G)=\frac{G}{6}\left\{\frac{9 K+8 G}{K+2 G}\right\}$

$E=\frac{9 K G}{G+3 K}$
The brackets $\{\cdot\}$ in Eqs. 7, 8 and 9 specify an average over the medium (which is similar as average over the constituents weighted by their volume fractions).

Based on the obtained values of $K$ and $G, £$ parameter was calculated $\left\{£\left(K_{\max }, G_{\max }\right)\right.$ and $\left.£\left(K_{\min } G_{\min }\right)\right\}$. Since $G_{\min }=0$, theoretically lower bound $E=0$. If the low Hashin-Shtrikman bound is zero for the Young's modulus, it does not mean that this bound does not exist. This means that the bounds are wide, and the modulus may vary within $200 \%$. Hence, the upper bound is plotted in Fig. 4d. Different clusters or trends of data can be interpreted, or classified, based on this plot. The plot may also be useful for understanding or extracting values for similar geological conditions as well as to understand the variability for conditions that are yet to be explored for interpreting potential moduli values or Vp values.

To analyse the effect of mineralogy on Poisson's ratio $(u)$, the volume percentage of major minerals was varied and $V p$ was calculated based on Eq. 2. Thereafter, $u$ was calculated as

$\left(\mathrm{V}_{\text {Calcite }}\right) \times\left(v_{\text {Calcite }}\right)+\left(\mathrm{V}_{\text {Dolomite }}\right) \times\left(v_{\text {Dolomite }}\right)=v$.

The tabulated datasets of $v$ and $V p$ obtained by varying the volume percentage of major minerals for sandstones and carbonates are presented in Table 5. A theoretical model represented in the form of Eq. 11 was used to analyse the effect of mineralogy on Poisson's ratio. The limitation of this model is that it does not take into account the effect of porosity and pore geometry.

\section{Results and discussion}

The different mechanical properties of rocks, Vp and Vs reported in this literature review were based on laboratory measurements under ambient conditions. Among the different literature data analysed, datasets labelled as B, C,
Table 7 Instrument used for evaluating UCS in the literature

\begin{tabular}{llll}
\hline Instrument/technique used & Associated literature & Sample & Location \\
\hline UCS instrument & 1. Madhubabu et al. [52] & Carbonate rocks & Gujarat, India \\
& 2. Kilic and Teymen [48] & Sandstone & Turkey \\
& 3. Pappalardo [63] & Sandstone & Sicily \\
& 4. Sarkar et al. [66] & Sandstone & Jutogh, India \\
& 5. Kurtulus et al. [51] & Limestone & Turkey \\
& 6. Moradian and Behnia [59] & Sandstone and limestone & Iran \\
\hline
\end{tabular}

\begin{tabular}{llll}
\hline Instrument/technique used & Associated literature & Sample & Location \\
\hline Brazilian tensile strength instrument & 1. Kilic and Teymen [48] & Sandstones & Turkey \\
& 2. Kurtulus et al. [51] & Limestones & Turkey
\end{tabular}

Table 8 Instrument used for evaluating indirect tensile strength in the literature 
Table 9 Summary of correlation laws between ultrasonic velocity $\left(\mathrm{V}_{\mathrm{p}}\right)$ and UCS available in the literature

\begin{tabular}{|c|c|c|c|c|}
\hline S No. & Parameters & Empirical relation & $s s^{2}$ & Reference \\
\hline 1 & UCS $(\mathrm{MPa})-\mathrm{V}_{\mathrm{p}}(\mathrm{km} / \mathrm{s})$ & $\mathrm{UCS}=35.4 \mathrm{~V}_{\mathrm{P}}-55$ & 0.80 & A \\
\hline 2 & UCS $(\mathrm{MPa})-\mathrm{V}_{\mathrm{p}}(\mathrm{m} / \mathrm{s})$ & $\mathrm{UCS}=0.035 \mathrm{~V}_{\mathrm{P}}-31.5$ & - & B \\
\hline 3 & UCS $(\mathrm{MPa})-\mathrm{V}_{\mathrm{p}}(\mathrm{m} / \mathrm{s})$ & $\begin{array}{l}\mathrm{UCS}=3.3 \times 10^{-20} \rho^{2} \mathrm{~V}_{\mathrm{p}}^{4}[(1+v) / \\
(1-v)]^{2}(1-2 v)\left[1+0.78 \mathrm{~V}_{\text {clay }}\right]\end{array}$ & - & $\mathrm{C}$ \\
\hline 4 & UCS $(\mathrm{MPa})-\mathrm{V}_{\mathrm{p}}(\mathrm{m} / \mathrm{s})$ & $\mathrm{UCS}=1.745 \times 10^{-9} \rho \mathrm{V}_{\mathrm{p}}^{2}-21$ & - & $E$ \\
\hline 5 & $\operatorname{UCS}(\mathrm{MPa})-\mathrm{V}_{\mathrm{p}}(\mathrm{km} / \mathrm{s})$ & $\mathrm{UCS}=9.95 \mathrm{~V}_{\mathrm{P}}^{1.21}$ & 0.83 & $\mathrm{~F}$ \\
\hline 6 & UCS (MPa) $-V_{p}(m / s)$ & $V_{P}=0.0317 U C S+2.0195$ & - & G \\
\hline 7 & UCS $(\mathrm{MPa})-\mathrm{V}_{\mathrm{p}}(\mathrm{km} / \mathrm{s})$ & $U C S=56.71 V_{p}-192.93$ & 0.67 & J \\
\hline 8 & UCS $(\mathrm{MPa})-\mathrm{V}_{\mathrm{p}}(\mathrm{km} / \mathrm{s})$ & $\mathrm{UCS}=2.304 \mathrm{~V}_{\mathrm{P}}^{2.4315}$ & 0.94 & 1 \\
\hline 9 & $\mathrm{UCS}(\mathrm{MPa})-\mathrm{V}_{\mathrm{p}}(\mathrm{m} / \mathrm{s})$ & $\mathrm{UCS}=165.05 \mathrm{e}^{\left(-4451.07 / \mathrm{V}_{\mathrm{p}}\right)}$ & 0.70 & $\mathrm{~N}$ \\
\hline 10 & UCS $(\mathrm{MPa})-\mathrm{V}_{\mathrm{p}}(\mathrm{m} / \mathrm{s})$ & $U C S=43 V_{P}+1000$ & - & $\mathrm{O}$ \\
\hline 11 & UCS $(\mathrm{MPa})-\mathrm{V}_{\mathrm{p}}(\mathrm{m} / \mathrm{s})$ & $U C S=0.038 V_{P}-50$ & 0.934 & $\mathrm{P}$ \\
\hline 12 & UCS $(\mathrm{MPa})-\mathrm{V}_{\mathrm{p}}(\mathrm{km} / \mathrm{s})$ & $U C S=7.812 V_{p}^{1.6}$ for $S_{r}=0$ & - & Q \\
\hline 13 & UCS $(\mathrm{MPa})-\mathrm{V}_{\mathrm{p}}(\mathrm{km} / \mathrm{s})$ & $\mathrm{UCS}=6.070 \mathrm{~V}_{\mathrm{p}}^{1.633}$ for $S_{\mathrm{r}}=0.2$ & - & Q \\
\hline 14 & UCS $(\mathrm{MPa})-\mathrm{V}_{\mathrm{p}}(\mathrm{km} / \mathrm{s})$ & $\mathrm{UCS}=4.937 \mathrm{~V}_{\mathrm{P}}^{1.673}$ for $S_{\mathrm{r}}=0.5$ & - & Q \\
\hline 15 & $\operatorname{UCS}(\mathrm{MPa})-\mathrm{V}_{\mathrm{p}}(\mathrm{km} / \mathrm{s})$ & $U C S=4.401 V_{P}^{1.684}$ for $S_{r}=0.7$ & - & $\mathrm{Q}$ \\
\hline 16 & UCS $(\mathrm{MPa})-\mathrm{V}_{\mathrm{p}}(\mathrm{m} / \mathrm{s})$ & $\mathrm{UCS}=5.61 * 10^{-9} \mathrm{~V}_{\mathrm{P}}^{2.75}$ & 0.86 & $\mathrm{R}$ \\
\hline 17 & UCS $(\mathrm{MPa})-\mathrm{V}_{\mathrm{p}}(\mathrm{km} / \mathrm{s})$ & $V_{P}=3.110+0.0289 U C S$ & 0.88 & $\mathrm{~S}$ \\
\hline 18 & UCS $(\mathrm{MPa})-\mathrm{V}_{\mathrm{p}}(\mathrm{m} / \mathrm{s})$ & $U C S=0.018 V_{P}-18.405$ & 0.93 & $\mathrm{~T}$ \\
\hline
\end{tabular}

Table 10 Summary of correlation laws between velocities $\left(\mathrm{V}_{\mathrm{p}}, \mathrm{V}_{\mathrm{s}}\right)$ and indirect tensile strength available in the literature

\begin{tabular}{|c|c|c|c|c|}
\hline S. no. & Parameters & Empirical relation & $\mathrm{R}^{2}$ & Reference \\
\hline 1 & $\sigma_{\mathrm{t}}(\mathrm{MPa})-\mathrm{V}_{\mathrm{p}}(\mathrm{km} / \mathrm{s})$ & $\sigma_{\mathrm{t}}=0.4935 \mathrm{~V}_{\mathrm{P}}^{1.8723}$ & 0.9216 & I \\
\hline 2 & $\sigma_{t}(\mathrm{MPa})-\mathrm{V}_{\mathrm{p}}(\mathrm{m} / \mathrm{s})$ & $\sigma_{\mathrm{t}}=0.348 \mathrm{e}^{0.0004 \mathrm{v}_{\mathrm{p}}}$ & 0.53 & $\mathrm{O}$ \\
\hline 3 & $\sigma_{\mathrm{t}}(\mathrm{MPa})-\mathrm{V}_{\mathrm{S}}(\mathrm{m} / \mathrm{s})$ & $\sigma_{\mathrm{t}}=0.277 \mathrm{e}^{0.0008 \mathrm{v}_{\mathrm{s}}}$ & 0.52 & $\mathrm{O}$ \\
\hline 4 & $\sigma_{\mathrm{t}}(\mathrm{MPa})-\mathrm{V}_{\mathrm{p}}(\mathrm{km} / \mathrm{s})$ & $\begin{aligned} \sigma_{\mathrm{t}} & =1.050 \mathrm{~V}_{\mathrm{p}}^{1.389} \text { for } \\
S_{\mathrm{r}} & =0\end{aligned}$ & - & Q \\
\hline 5 & $\sigma_{t}(\mathrm{MPa})-\mathrm{V}_{\mathrm{p}}(\mathrm{km} / \mathrm{s})$ & $\begin{array}{c}\sigma_{t}=0.919 V_{p}^{1.416} \text { for } \\
S_{r}=0.2\end{array}$ & - & Q \\
\hline 6 & $\sigma_{\mathrm{t}}(\mathrm{MPa})-\mathrm{V}_{\mathrm{p}}(\mathrm{km} / \mathrm{s})$ & $\begin{array}{c}\sigma_{\mathrm{t}}=0.767 \mathrm{~V}_{\mathrm{P}}^{1.444} \text { for } \\
S_{\mathrm{r}}=0.5\end{array}$ & - & $\mathrm{Q}$ \\
\hline 7 & $\sigma_{\mathrm{t}}(\mathrm{MPa})-\mathrm{V}_{\mathrm{p}}(\mathrm{km} / \mathrm{s})$ & $\begin{array}{c}\sigma_{\mathrm{t}}=0.694 \mathrm{~V}_{\mathrm{p}}^{1.447} \text { for } \\
S_{\mathrm{r}}=0.7\end{array}$ & - & $\mathrm{Q}$ \\
\hline 8 & $\sigma_{\mathrm{t}}(\mathrm{MPa})-\mathrm{V}_{\mathrm{p}}(\mathrm{km} / \mathrm{s})$ & $\begin{array}{l}\sigma_{\mathrm{t}}=0.583 \mathrm{~V}_{\mathrm{p}}^{1.473} \text { for } \\
S_{\mathrm{r}}=1\end{array}$ & - & Q \\
\hline
\end{tabular}

$D, E$ represent sandstones, datasets labelled as $A, F, G, L, S$, $\mathrm{T}, \mathrm{U}$ represent carbonate rocks, while datasets labelled as $\mathrm{H}, \mathrm{I}, \mathrm{J}, \mathrm{N}, \mathrm{O}, \mathrm{P}, \mathrm{Q}$ consist of an amalgamation of a variety of rocks as summarised in Table 1. The correlations/empirical formulations among mechanical properties and Vp, Vs for reservoir rocks were examined/plotted/tabulated.

\subsection{Rock strength}

Suitable core for testing is not always available, and in the absence of cores, correlations can be used to estimate strength. $[14,15,20,22,23,42,45,48,51,54,57-59,63$, $64,66,70,73,75,83]$ established empirical correlations between UCS, tensile strength and $\mathrm{Vp}$. These relationships are shown in Tables 7 and 8, respectively. Tables 9 and 10 present the instrument/technique used for evaluating UCS and indirect tensile strengths in the literature.

Correlation between UCS and ultrasonic tests on 13 samples of numerous carbonate rock types around Antara, Turkey, reported a $R^{2}$ of 0.80 [83], by using simple linear relations, while analysis [59] in three different sedimentary rock types (sandstone, limestone and marlstone) around various dam sites in Iran reported $R^{2} 0.70$. However, velocity values were multiplied by density values to obtain a better regression coefficient between UCS and Vp. Correlation coefficient improved to 0.75 as against $0.70 . R^{2}$ of 0.9022 was reported [70] on tests carried out on seven types of rock (one igneous, three sedimentary and three metamorphic). Similarly, an empirical correlation was reported [42] between $V p$ and UCS with $R^{2} 0.83$. A correlation with $R^{2} 0.67$ [14] was described for two rock types only, while [66] reported $R^{2} 0.934$. A strong linear dependence on UPV with a $R^{2} 0.93$ was reported [51]. Analysis [48] carried out on 19 rock types comprising of ten igneous rocks (seven of which were volcanic), seven sedimentary and two metamorphic of southern Anatolia location, correlated the $\mathrm{Vp}$ and the indirect tensile strength and reported a strong correlation with a $R^{2} 0.9216$. Empirical equations were presented [45] between $V p$ and the indirect tensile strength for different degrees of saturation values. 

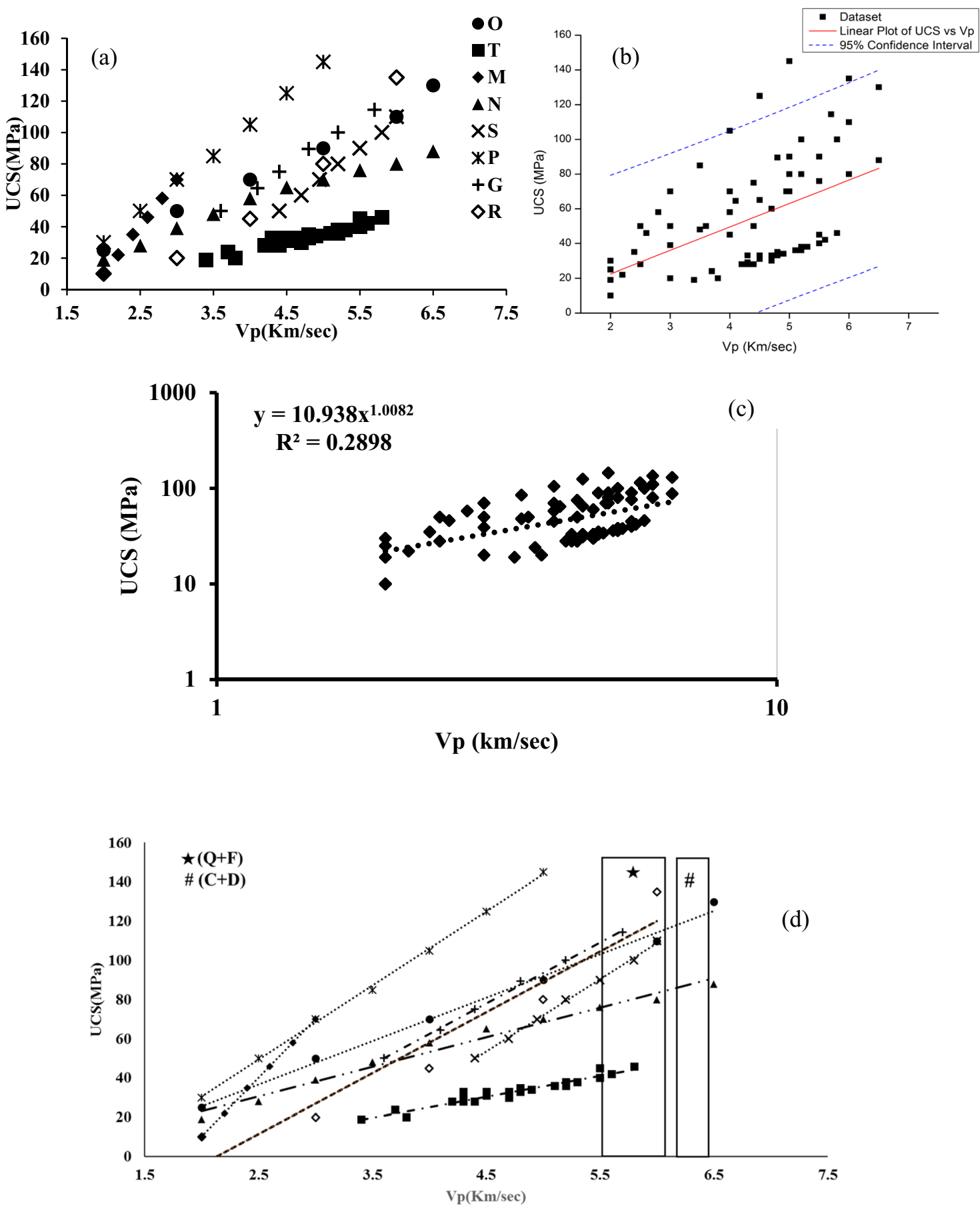

Fig. 2 Variation of uniaxial compressive strength with the compressional wave velocity a as per studies of several researchers, b including general trend derived from this study using simple regression analysis and confidence interval, c data plotted on a log-log scale indicating nonlinear nature of the relationship, $\mathbf{d}$ graphical representation of UCS versus $\mathrm{Vp}$, as reported by different researchers along with their trend line $[51,59,63,64,66,70,73$,
83]. The marked rectangle shows the range of Vp values for sandstones $(5.7-6 \mathrm{~km} / \mathrm{s})$ when considering the effect of varying mineral contents ${ }^{*}$ major minerals $\mathrm{Q}$ - quartz and $\mathrm{F}$-feldspar with varying proportions (75\% Q, 25\% F, 80\% Q, 20\% F, till 100\% Q, 0\% F), while for carbonates, $\mathrm{Vp}$ varies from 6.25 to $6.43 \mathrm{~km} / \mathrm{s}$ for varying major minerals (\# C-calcite and D-dolomite) proportions (100\% C, 0\% D till $75 \%$ C, 25\% D) 

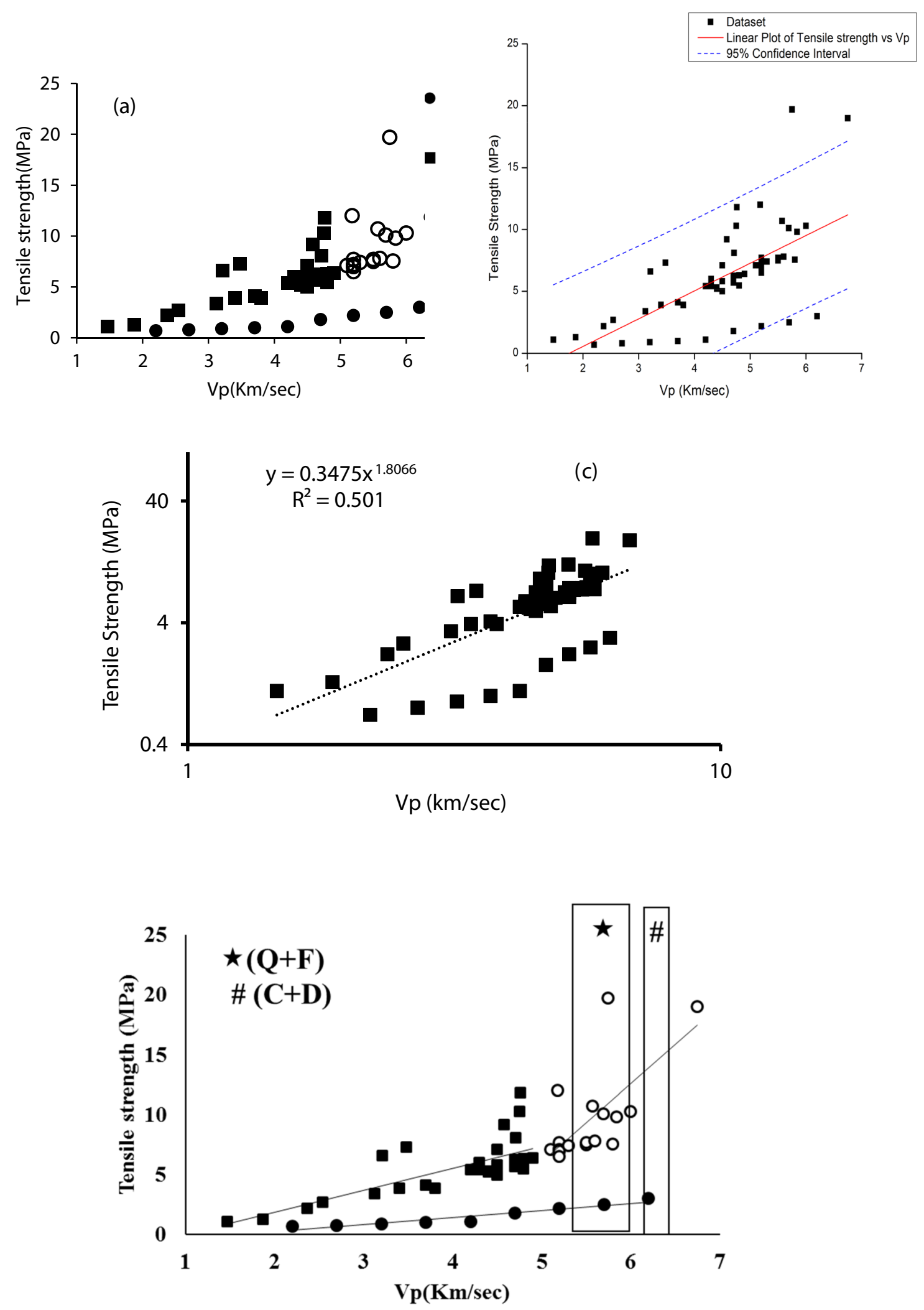
4 Fig. 3 Variation of indirect tensile strength with the compressional wave velocity $\mathbf{a}$ as per studies of several researchers, $\mathbf{b}$ including general trend derived from this study using simple regression analysis and confidence interval, $\mathbf{c}$ data plotted on a log-log scale indicating nonlinear nature of the relationship, $\mathbf{d}$ graphical representation of indirect tensile strength versus $V p$, as reported by different researchers along with their trend line $[48,51,73]$. The marked rectangles show the range of Vp values for sandstones $(5.7-6 \mathrm{~km} / \mathrm{s})$ when considering the effect of varying mineral contents $(*$ major minerals Q-quartz and $\mathrm{F}$-feldspar with varying proportions $(75 \%$ $\mathrm{Q}, 25 \% \mathrm{~F}$ till $65 \% \mathrm{Q}, 35 \% \mathrm{~F}$ ), while for carbonates, Vp varies from 6.25 to $6.43 \mathrm{~km} / \mathrm{s}$ for varying major minerals (\# C-calcite and Ddolomite) proportions (100\% C, 0\% D till 75\% C, 25\% D)

The variation of UCS and $\sigma_{\mathrm{t}}$ with $\mathrm{Vp}$ observed by various researchers is presented in Figs. 2 and 3, respectively. It is observed from Fig. 2 that the UCS value of limestone from Turkey location (label T in Table 1) varies from 19 to $46 \mathrm{MPa}$ with a change in Vp from 3.4 to $5.8 \mathrm{~km} / \mathrm{s}$. Comparatively, the UCS value of limestone from Paris location (label $R$ in Table 1) varies from 20 to $135 \mathrm{MPa}$ with a change in $\mathrm{Vp}$ from 3 to $6 \mathrm{~km} / \mathrm{s}$. The percentage increase thus observed in UCS from Turkey location (label T) is $142 \%$, while the percentage increase in UCS from Paris location (label R) is $575 \%$. The indirect tensile strength values, as observed from Fig. 3, vary from 0.7 to $19.7 \mathrm{MPa}$ and $\mathrm{Vp}$ range is $1.47-6.75 \mathrm{~km} / \mathrm{s}$. Significant results [54] showed wide variability in the velocity values for individual rock types as against a limited range of UCS values. They obtained a correlation coefficient of $0.94, R^{2}$ value of 0.88 . For a multiplicative model of the form, $y=a x^{b}$. In spite of obtaining a good correlation between UCS and Vp, still researcher [54] suggested caution in deriving strength values and vice versa owing to the scattering of data points (large variation in Vp values for a limited range of UCS values) indicating nonlinear nature of the relationship. However, to improve the accuracy of deriving strength values from velocity measurements, the mineralogy of the rock needs to be investigated. For instance, the dependency of velocity measurements on an increase or decrease in quartz or feldspar content for sandstones and calcite or dolomite content for carbonates may be examined. Nevertheless, velocity measurements may be utilised to give a varied indication of disparity in rock mass strength.

To understand the link between the strength properties and $V p$, the combined graphical representation of variation of UCS and tensile strength (indirect tensile strength) with $\mathrm{Vp}$ is plotted in Figs. 3 and 4, respectively, where Figs. 3 and $4 a$ illustrate data as reported by different researchers; Figs. 3 and $4 \mathrm{~b}$ illustrate data including general trend derived from this study using simple regression analysis and confidence interval; and Figs. 3 and 4c illustrate data plotted on a log-log scale indicating nonlinear relationship. The confidence intervals were set at $95 \%$, as most of the raw data fall within this range. Hence, from the plotted graphs, it is observed that both UCS and tensile strength increase with an increase in $\mathrm{Vp}$. However, there is a wide variation in the strength values, and for a particular value of $\mathrm{Vp}$, there exist two values of rock strength (UCS and tensile strength). This scattering of data results may be due to some other influential factors like mineralogical composition or higher clay content leading to an alteration in mechanical and elastic properties of rocks, thereby showing the dispersion of data points in the graph. Moreover, it is observed that carbonate rocks have a higher value of UCS as compared to sandstones which can be attributed to a greater value of density, thereby resulting in a higher value of $V p$ for carbonate rocks.

An attempt is made to present the nonlinear relationship between UCS, indirect tensile strength with $V p$, as shown in Figs. 2c and 3c. A log-log graph is plotted since a reasonable straight line relationship is obtained on doing so; however, obtained $R^{2}$ is 0.28 (presented in the form of $y=a x^{b}$ ) for UCS-Vp and $R^{2}$ is 0.49 (of the form $y=a x^{b}$ ) for indirect tensile strength- $V p$ plot. The scatter is observed due to the presence of outliers. For UCS-Vp plot, the variation in Vp is observed to be as low as 2-6.5 km/s. Similarly, for tensile strength- $V p$ plot, the variation in $V p$ is observed to be as low as $2.2-6.75 \mathrm{~km} / \mathrm{s}$. Ideally, major mineral present in sandstone has a Vp of $6.057 \mathrm{~km} / \mathrm{s}$ (quartz's grain density is $2.65 \mathrm{~g} / \mathrm{cc}$ ) [16], while, for the case of carbonates, $V p$ is $6.259 \mathrm{~km} / \mathrm{s}$ corresponding to major mineral calcite with grain density of $2.71 \mathrm{~g} / \mathrm{cc}$ [16]. However, these Vp values are the maximum (for zero porosity). Table 4 presents a compilation illustrating different parameter values for different minerals. Thus, any variation in the $V p$ value corresponds to an alteration in porosity value. For instance, minimum value of $V p$ obtained from the study is $2 \mathrm{~km} / \mathrm{s}$, maybe indicating high porosity of the same sample. This is because an increase in porosity is always associated by an equivalent decrease in $\mathrm{Vp}$, since seismic velocity in the pores is less than the grains of which the rocks are composed of. The $V p$ values, so obtained by fragmented analysis, are plotted in Fig. 2d for UCS-Vp plot and Fig. 3d for indirect tensile strength-Vp plot. The marked rectangles in Figs. $2 \mathrm{~d}$ and $3 \mathrm{~d}$ show the range of $\mathrm{Vp}$ values for sandstones $(5.7-6 \mathrm{~km} / \mathrm{s})$ and carbonates $(6.25-6.43 \mathrm{~km} / \mathrm{s})$ when considering the effect of varying mineral contents. However, apart from mineralogy, porosity and saturation also have an influence on the alteration of the geomechanical properties. The presence of clay minerals could also lead to a deviation in Vp values. Also, Vp increases with increasing saturation and also depends on the type of fluid (Tables 4 and 6). Hence, to be more precise when assessing rock mass conditions, this inclusive study (considering all influential parameters) may be carried out so as to be more reliable when dealing in different stages of an investigation. However, it is important here to mention 

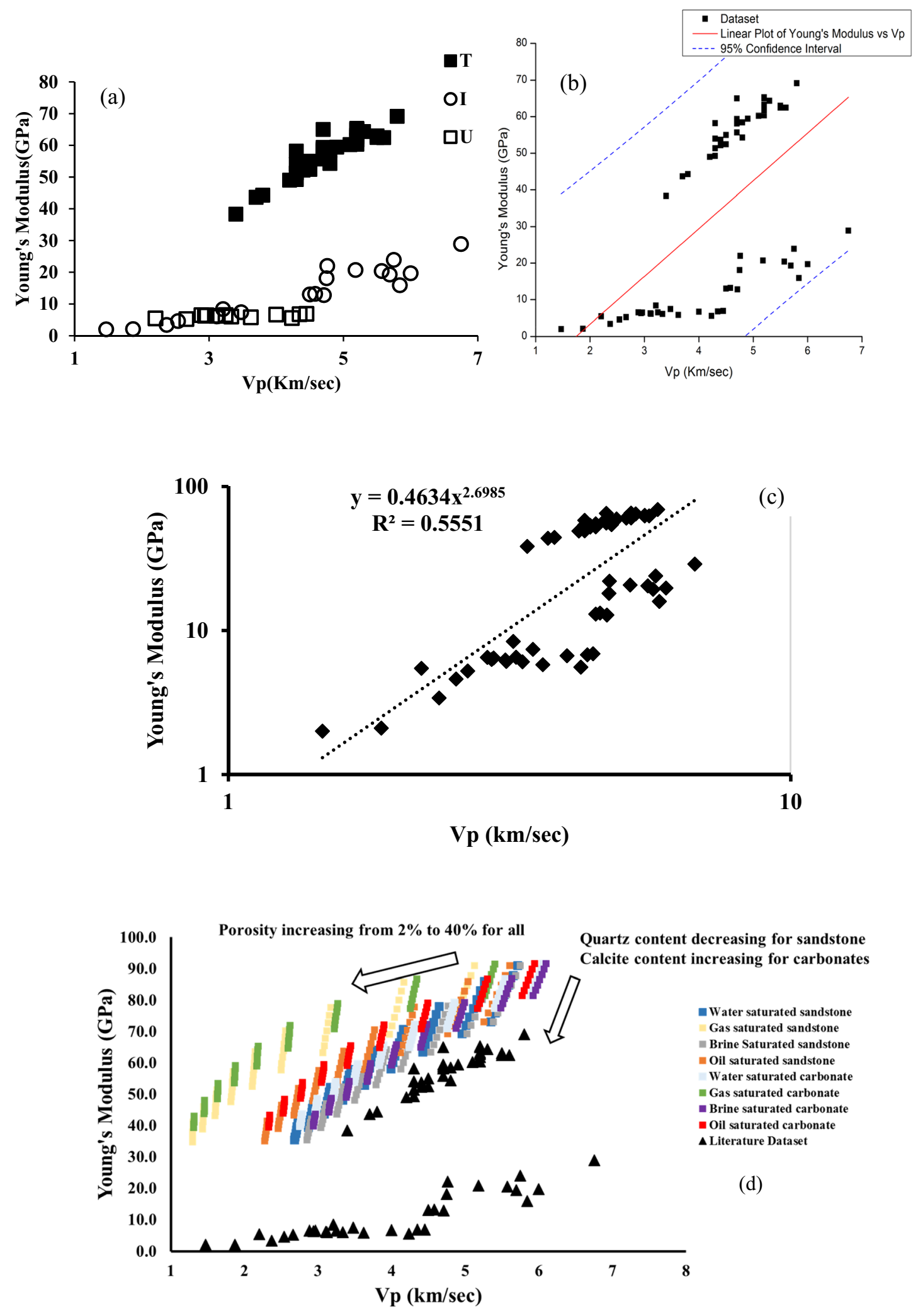
4Fig. 4 Variation of Young's modulus with the compressional wave velocity $\mathbf{a}$ as per studies of several researchers, $\mathbf{b}$ including general trend derived from this study using simple regression analysis and confidence interval, c data plotted on a log-log scale indicating nonlinear nature of the relationship, $\mathbf{d}$ graphical representation of $E$ versus $V p$ for different geological scenarios along with incorporating the effect of varying porosity and mineral composition, including literature dataset

that it is improbable that $V p$ values may ever substitute the mechanically derived parameters, although a suggestion of the variation can be noted or a comparative study of different geomechanical properties of various lithological units can be investigated. These seismic measurements can be viewed as complementary and equally important for studies related to the evaluation of rock mass performance (geomechanical classification system).

\subsection{Modulus of Elasticity}

The prediction of elastic modulus $(E)$ can be made from the measurement of $V p$ and $V s$ since $E$ is an important parameter for intact rock classification and criteria for rock failure. The laboratory determination of $E$ involves rigorous, time-consuming and destructive testing. Hence, ultrasonic techniques can be utilised to provide a direct evaluation of the rock mass. Thus, studies by [51, $59,63,64,83]$ were conducted to establish a relationship between the two as shown in Fig. 4. Many correlations have been reported as shown in Table 11. The range of Young's modulus values found from graph is 2-69.14 GPa and $V p$ range is $1.47-6.75 \mathrm{~km} / \mathrm{s}$. Yasar and Erdogan [83] found regression coefficient 0.86 for studies conducted on carbonate rocks, Parent et al. [64] and Kurtulus et al. [51] 0.77 and 0.76, respectively, for limestones, Pappalardo [63] 0.80 for dolostone, while [59] reported the highest regression coefficient value of 0.92 .

To understand the correlation between $E$ and Vp, different datasets were compiled from the literature and a combined graphical representation of its variation is plotted in Fig. 4, where Fig. 4a illustrates datasets as reported by different researchers; Fig. $4 \mathrm{~b}$ illustrates datasets including general trend derived from this study using simple regression analysis and confidence interval; and Fig. 4c illustrates data plotted on a log-log scale indicating nonlinear relationship (of the form $y=a x^{b}$, with $R^{2}=0.55$ ). The confidence intervals were set at $95 \%$. From the plotted graph, modulus of elasticity increases with an increase in $\mathrm{Vp}$. However, for a particular value of $V p$ there exist two values of $E$. Such a wide variation may be due to the change in mineralogical composition (rock composition and texture, clay content, anisotropy, etc.) leading to an alteration in mechanical and elastic properties of rocks. Moreover, there are fundamental differences between sandstone and carbonate rocks. Carbonates are autochthonous, while sandstones are allochthonous; carbonate minerals have a greater chemical reactivity $[13,19,56]$. These differences in sandstones and carbonates lead to the variation in parameters. The density of minerals that constitute sandstones and carbonates varies as summarised in Table 4 . The density of major minerals in carbonates (calcite and dolomite) has a relatively higher value than the density of major minerals in sandstones (quartz and feldspar). This variation in density also leads to the alteration in the geomechanical properties of sandstones and carbonates. As discussed in methodology, by using the formulation of Hashin-Shtrikman-Walpole bounds [5], it was found that lower bound does not exist and only upper bound is prevailing. Based on this, the variation of $E$ with $\mathrm{Vp}$ is analysed and the template is presented in Fig. $4 \mathrm{~d}$. This template can be used to predict the elastic properties for different geological scenarios that include water-saturated, gas-saturated, brine-saturated and oil-saturated conditions for sandstones and carbonates along with the literature dataset ([51]—label T, [48] —label I and [52] label $U$ ). The plotted datasets highlight several salient features.

- With an increase in porosity from 2 to $40 \%$, there is a decrease in $E$ and $V p$ values for all types of saturation scenarios for sandstones and carbonates;

- With an increase in quartz content and subsequent decrease in feldspar content in sandstones, $E$ and $V p$ increase (owing to higher density of quartz mineral as compared to feldspar mineral), while for carbonates, with an increase in calcite content and subsequent decrease in dolomite content, $E$ and $V p$ decrease (owing to higher density of dolomite mineral as compared to calcite mineral);

- Carbonates have a higher value of $E$ and $V p$ than sandstones (higher density of minerals found in carbonates than sandstones) for all particular sets of saturation conditions.

- More or less, there is an approximate $50 \%$ reduction in $\mathrm{Vp}$ and $E$ values for a porosity increase from 2 to $40 \%$.

Thus, the plotted figure will help to understand the variability of $\mathrm{Vp}$ values associated with the change in saturation conditions for a reservoir rock under investigation. Such a template would aid in the interpretation of geomechanical behaviour of rocks on the basis of $\mathrm{Vp}$ values, even in the absence of well log data. However, the present template considers the effect of only major minerals and porosity. Other factors such as the presence of other minor minerals and clay content may also alter the properties, which may be one of the reasons for literature 
Table 11 Summary of correlation laws between ultrasonic velocities $\left(V_{p}, V_{s}\right)$ and Young's modulus available in the literature

\begin{tabular}{lllll}
\hline S. no. & Parameters & Empirical relation & $R^{2}$ & Reference \\
\hline 1 & $E(\mathrm{GPa})-\mathrm{V}_{\mathrm{p}}(\mathrm{km} / \mathrm{s})$ & $\mathrm{V}_{\mathrm{p}}=0.0937 E+1.7528$ & 0.86 & $\mathrm{G}$ \\
2 & $E(\mathrm{GPa})-\mathrm{V}_{\mathrm{p}}(\mathrm{m} / \mathrm{s})$ & $E=0.965 \mathrm{~V}_{\mathrm{p}}^{0.810}$ & 0.77 & $\mathrm{R}$ \\
3 & $E(\mathrm{GPa})-\mathrm{V}_{\mathrm{p}}(\mathrm{m} / \mathrm{s})$ & $E=2.06 \mathrm{~V}_{\mathrm{p}}^{2.78}$ & 0.92 & $\mathrm{~N}$ \\
4 & $E(\mathrm{MPa})-\mathrm{V}_{\mathrm{p}}(\mathrm{km} / \mathrm{s})$ & $E=-15718.21+5075.79 \mathrm{~V}_{\mathrm{p}}$ & 0.80 & $\mathrm{~S}$ \\
5 & $E(\mathrm{GPa})-\mathrm{V}_{\mathrm{p}}(\mathrm{m} / \mathrm{s})$ & $E=0.0114 \mathrm{~V}_{\mathrm{p}}+3.7059$ & 0.76 & $\mathrm{~T}$ \\
\hline
\end{tabular}

Table 12 Summary of correlation laws between ultrasonic velocity $\left(V_{p}\right)$ and Poisson's ratio available in the literature

\begin{tabular}{lllll}
\hline S. no. & Parameters & Empirical relation & $R^{2}$ & Reference \\
\hline 1 & $u-\mathrm{V}_{\mathrm{p}}(\mathrm{m} / \mathrm{s})$ & $v=0.152 \mathrm{~V}_{\mathrm{p}}^{0.126}$ & 0.67 & $\mathrm{R}$ \\
2 & $u-\mathrm{V}_{\mathrm{p}}(\mathrm{m} / \mathrm{s})$ & $v=-5 E-0.5 \mathrm{~V}_{\mathrm{p}}+0.6$ & 0.85 & $\mathrm{~T}$ \\
\hline
\end{tabular}

dataset falling below the modelled template dataset. Thus, it can be inferred that a material with higher $E$ will have a higher $\mathrm{Vp}$, due to higher density and presence of lower pores (lower porosity). A comprehensive study on the correlations between porosity, elastic moduli, Poisson's ratio and seismic velocity for solid materials and rocks may be referred $[34,85]$.

However, it is to be noted that the modulus of elasticity estimated from the measurement of $\mathrm{Vp}, \mathrm{Vs}$ is dynamic elastic modulus and not static modulus [45, 54]. For most design purposes, static modulus will be required to obtain deformation behaviour. Dynamic modulus can be used where dynamic loading is involved. Nevertheless, the static modulus is generally lesser than the dynamic modulus and the literature establishing the correlations between the two for various types of rock is available [7]. This variation in modulus values may possibly be due to the broadly used strain levels at which two sets of measurements are made [54]. It was also suggested [82] that majority of the variation between static and dynamic elastic moduli is because of viscoelastic effects or inelastic deformation occurring inside the rock, since the frequency variation among dynamic and static measurements is sufficiently large to permit viscoelastic deformation in static tests that would not happen on deformation timescale of elastic wave used to estimate dynamic moduli [67]. However, if testing is done at high stress levels and under pressure, there is an agreement between the two measurements [49]. Nonetheless, E values obtained from Vp, Vs measurements may be used for qualitative comparative measurements as an indicator of geomechanical behaviour.

\subsection{Poisson's ratio}

Among the elastic properties, $v$ is the least studied, but at the same time the most interesting [26]. $v$ is defined as the ratio of a decrease in transverse dimension to that of an increase in axial dimension when subjected to uniaxial stress for an isotropic material. At a given temperature and a given pressure, $u$ is constant for an isotropic material and its values lie between -1 and 0.5 . A comprehensive analysis [35] on $v$ and auxetic properties of natural rocks may be referred for further study. Empirical equations were reported $[51,64]$ as shown in Table 12. Parent et al. [64] and Kurtulus et al. [51] gave empirical equations with regression coefficient values of 0.67 and 0.85 , respectively, for limestone. To understand the association between $v$ and $\mathrm{Vp}$, combined graphical representation of its variation is presented in Fig. 5, where Fig. 5a illustrates data as reported by different researchers; Fig. $5 \mathrm{~b}$ illustrates data including general trend derived from this study using simple regression analysis and confidence interval; and Fig. $5 \mathrm{c}$ illustrates data plotted with calcite mineral values showing alteration. The confidence intervals were set at $95 \%$. The range of Poisson's ratio values found from graph is $0.23-0.4$ and Vp range is $2.2-5.8 \mathrm{~km} / \mathrm{s}$. From the plotted graph, it is observed that as Vp increases, $v$ decreases or there is a negative linear correlation between them. Hence, a decrease in $v$ is linked with an increase in $V p$, which further leads to an increase in $E$. Ideally for limestone samples, the major mineral present would be calcite with a value of Poisson's ratio 0.316 and $V p 6.259 \mathrm{~km} / \mathrm{s}$. However, as explained earlier, due to the influence of several factors (mineralogy, porosity, saturation), there occurs a deviation from these values. As discussed in methodology, to account for the mineralogy effect on $V p$, the generated dataset of $\mathrm{Vp}-u$ is plotted with the existing dataset from the literature, as shown in Fig. $5 \mathrm{~d}$. The circled part depicts the decrease in Poisson's ratio values with a decrease in calcite and an increase in dolomite content, thereby highlighting the effect of mineral content on $\mathrm{Vp}$ values and thus on Poisson's ratio. Moreover, the effect of porosity and clay content (if present) was not considered which may also add to the dispersion in the values. The influence of porosity on $v$ of natural rocks is limited due to lack of experimental data over different porosity and pore geometry ranges [85]. However, studies [18, 78, 85] provide a comprehensive review on $v$ and may be referred for further study.

Different correlations [6] among Vp, Vs, density, $u$ for a wide variety of common lithology have been analysed. These measurements were compiled from wireline borehole logs, vertical seismic profiles, laboratory or field measurements and in situ estimates from seismic tomography studies. Correlations between Vp, Vs and $u$ were analysed 

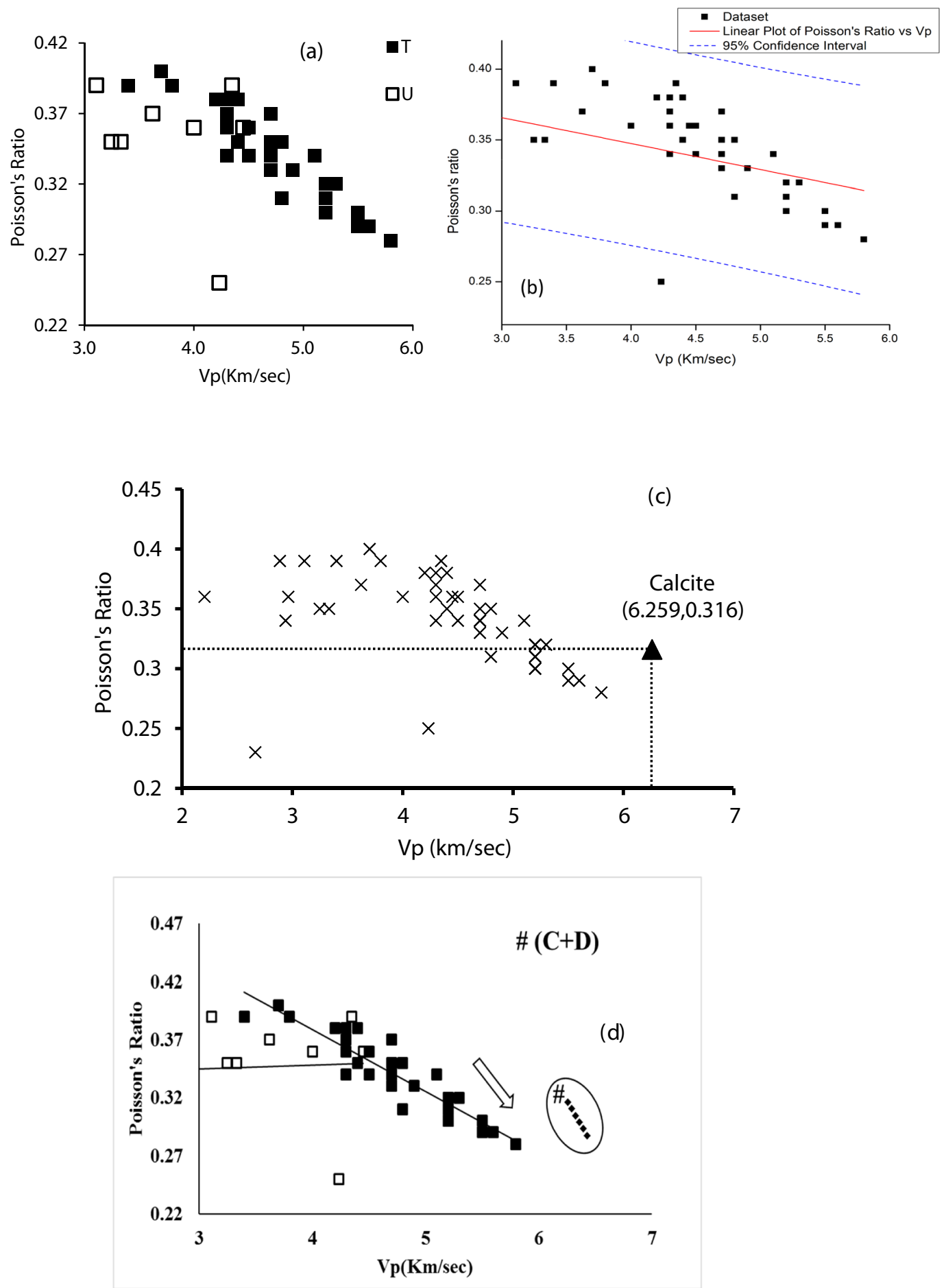

Fig. 5 Variation of Poisson's ratio with the compressional wave velocity a as per studies of several researchers, b including general trend derived from this study using simple regression analysis and confidence interval, $\mathbf{c}$ data plotted with calcite mineral values showing alteration, $\mathbf{d}$ graphical representation of Poisson's ratio versus $\mathrm{Vp}$, as reported by different researchers along with their trend line [51, 52]. Label \# represents limestone major minerals (C-calcite and D-dolomite) different proportions (75\% C, 25\% D, $80 \%$ C, $20 \%$ D, till $100 \%$ C, $0 \%$ D). The circled part depicts the decrease in Poisson's ratio values with a decrease in calcite and an increase in dolomite content, thereby highlighting the effect of mineral content on Vp values and thus on Poisson's ratio 

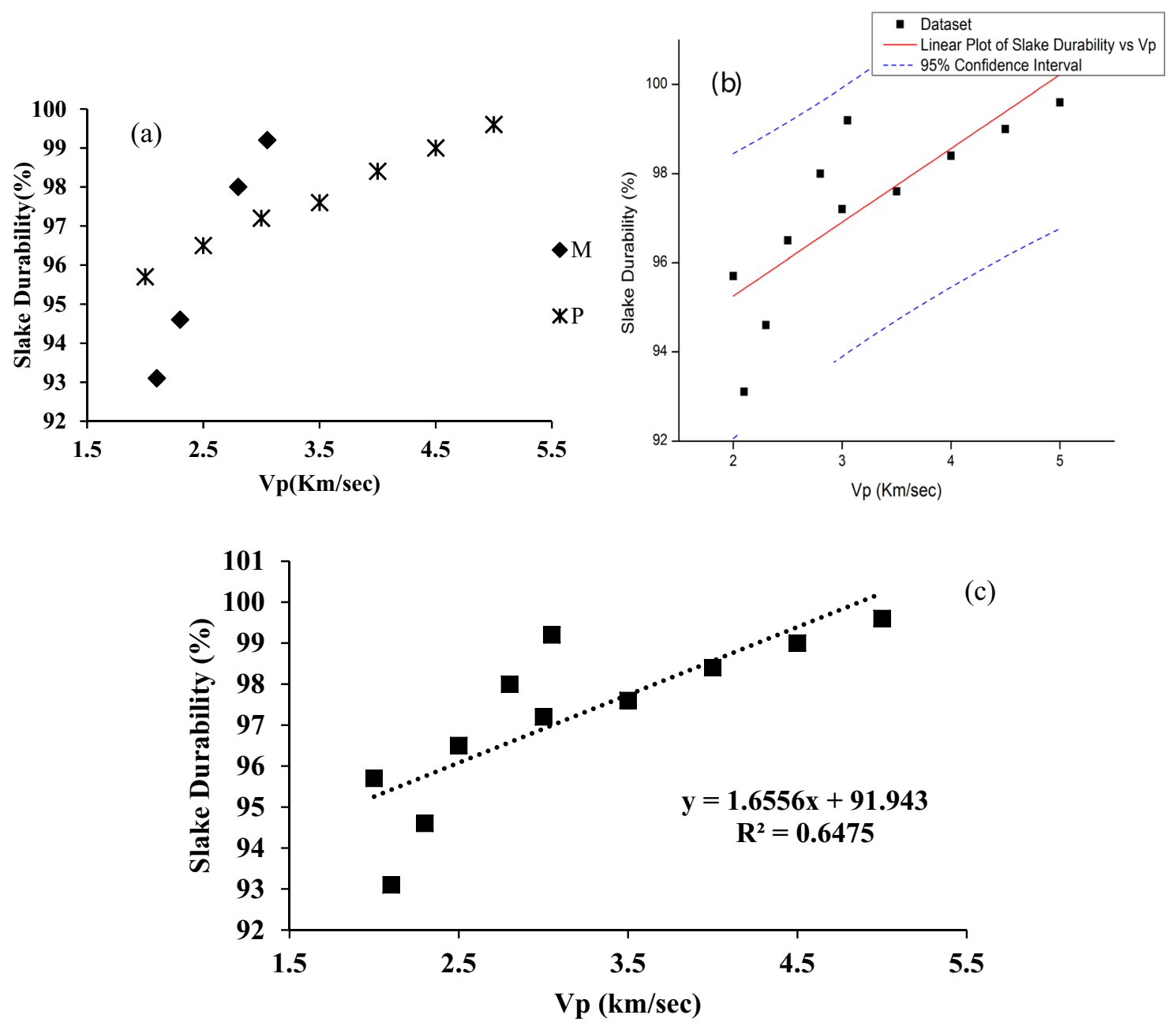

Fig. 6 Variation of slake durability with the compressional wave velocity $\mathbf{a}$ as per studies of several researchers, $\mathbf{b}$ including general trend derived from this study using simple regression analysis and confidence interval, $\mathbf{c}$ data plotted showing linear nature of the relationship

Table 13 Summary of correlation laws between ultrasonic velocity $\left(V_{p}\right)$ and slake durability index available in the literature

\begin{tabular}{lllll}
\hline S. no. & Parameters & Empirical relation & $\mathrm{R}^{2}$ & Reference \\
\hline 1 & SDI $(\%)-\mathrm{V}_{\mathrm{P}}(\mathrm{m} / \mathrm{s})$ & $\mathrm{SDI}=0.0069 \mathrm{~V}_{\mathrm{P}}+78.5770 .7831$ & $\mathrm{M}$ \\
2 & $\mathrm{SDI}(\%)-\mathrm{V}_{\mathrm{P}}(\mathrm{m} / \mathrm{s})$ & $\mathrm{SDI}=0.0014 \mathrm{~V}_{\mathrm{P}}+92.980 .904$ & $\mathrm{P}$ \\
\hline
\end{tabular}

$[78,79]$ for different rocks (common rocks and sulphide ores) based on high-pressure laboratory measurements of $V p$ and Vs. Moreover, this study [36] analysed in detail the characteristic Lame's $(\chi)$ parameter values of common rocks in the Earth's crust and upper mantle and presented $\chi$ as a function of pressure, temperature and mineralogy.

\subsection{Other parameters}

Some of the other parameters that can be predicted using ultrasonic velocity include slake durability index (SDI) and point load strength [70]. In this paper, the data corresponding to slake durability are limited (low number of datasets available). A probable reason may be since slake durability is partially controlled by strength, indicating a coherent relation among them, and studies related to $\mathrm{Vp}$-strength (UCS, indirect tensile strength) correlation were already studied by different researchers, as also discussed in the earlier sections. The presence of clay minerals would also play a major role for slake durability studies.

To understand the association between SDI and $V p$, combined graphical representation of its variation is presented in Fig. 6, where Fig. 6a illustrates data as reported by different researchers; Fig. $6 \mathrm{~b}$ illustrates data including general trend derived from this study using 

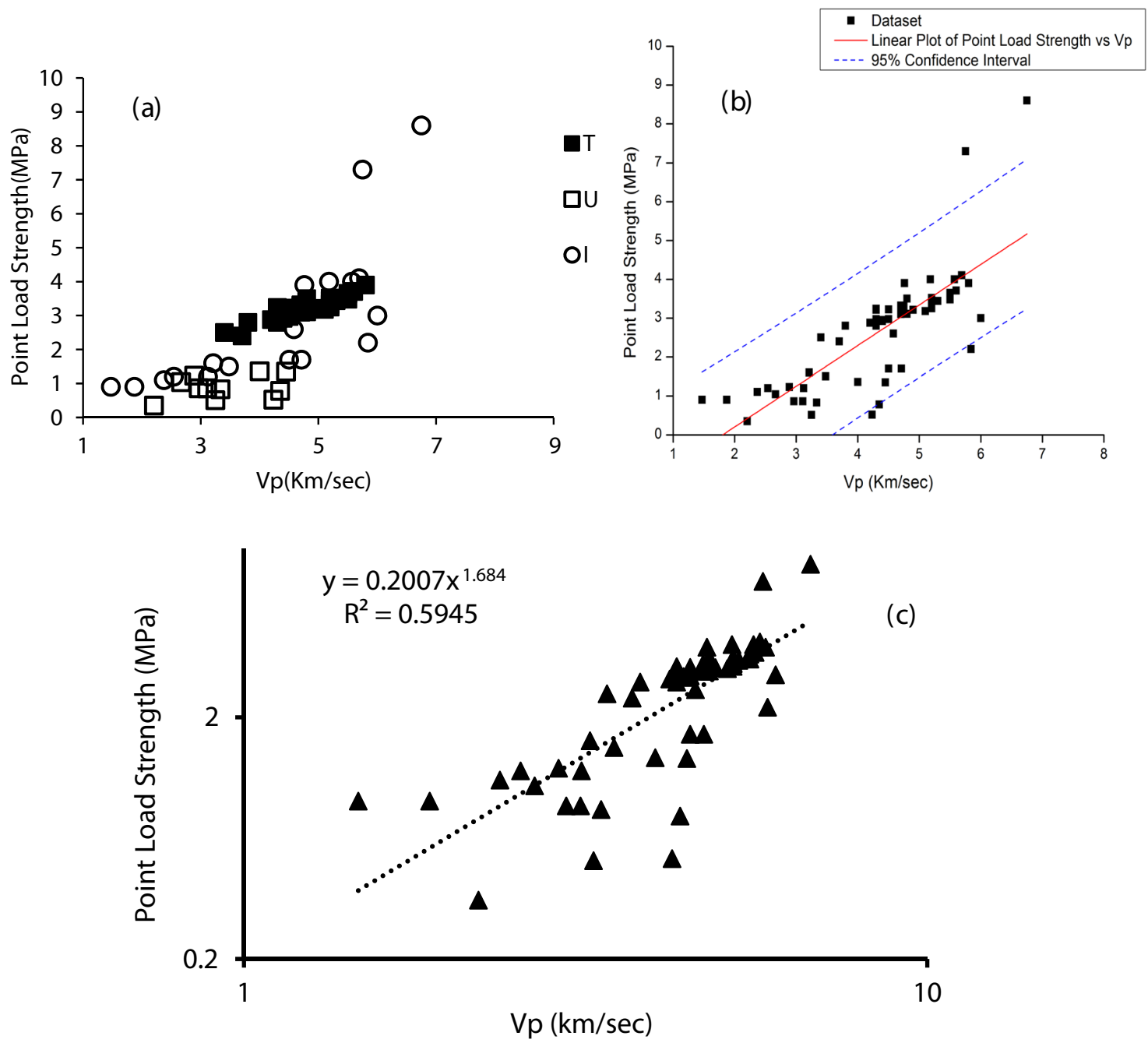

Fig. 7 Variation of point load strength with the compressional wave velocity a as per studies of several researchers, $\mathbf{b}$ including general trend derived from this study using simple regression anal-

ysis and confidence interval, $\mathbf{c}$ data plotted on a log-log scale indicating nonlinear nature of the relationship
Table 14 Summary of correlation laws between ultrasonic velocities $\left(\mathrm{V}_{\mathrm{p}}, \mathrm{V}_{\mathrm{s}}\right)$ and other parameters available in the literature

\begin{tabular}{lllll}
\hline S. no. & Parameters & Empirical relation & $R^{2}$ & Reference \\
\hline 1 & $\mathrm{~V}_{\mathrm{P}}(\mathrm{km} / \mathrm{s})-\mathrm{V}_{\mathrm{S}}(\mathrm{km} / \mathrm{s})$ & $\mathrm{V}_{\mathrm{P}} / \mathrm{V}_{\mathrm{S}}=1.55+0.56 n+0.43 \mathrm{C}$ & - & $\mathrm{D}$ \\
2 & $\mathrm{~V}_{\mathrm{P}}(\mathrm{km} / \mathrm{s})-\mathrm{V}_{\mathrm{S}}(\mathrm{km} / \mathrm{s})$ & $\mathrm{V}_{\mathrm{P}}=1.26 \mathrm{~V}_{\mathrm{S}}+1.07$ & - & $\mathrm{D}$ \\
3 & $\mathrm{~V}\left(\mathrm{~cm}^{3} / 50 \mathrm{~cm}^{2}\right)-\mathrm{V}_{\mathrm{P}}(\mathrm{km} / \mathrm{s})$ & $\mathrm{V}=57997 \mathrm{~V}_{\mathrm{P}}^{-2.4279}$ & 0.8452 & $\mathrm{I}$ \\
4 & $\mathrm{~V}_{S}(\mathrm{~m} / \mathrm{s})-\mathrm{V}_{\mathrm{P}}(\mathrm{m} / \mathrm{s})$ & $\mathrm{V}_{S}=0.456 \mathrm{~V}_{\mathrm{P}}+264.3$ & 0.90 & $\mathrm{O}$ \\
5 & $\tau(\mathrm{MPa})-\mathrm{V}_{\mathrm{P}}(\mathrm{m} / \mathrm{s})$ & $\tau=0.0019 \mathrm{~V}_{\mathrm{P}}-2.6545$ & 0.90 & $\mathrm{~T}$ \\
6 & $I_{S}(\mathrm{MPa})-\mathrm{V}_{\mathrm{P}}(\mathrm{m} / \mathrm{s})$ & $I_{S}=0.0005 \mathrm{~V}_{\mathrm{P}}+0.659$ & 0.83 & $\mathrm{~T}$ \\
7 & $I_{S}(\mathrm{MPa})-\mathrm{V}_{\mathrm{P}}(\mathrm{m} / \mathrm{s})$ & $I_{S}=0.022 \mathrm{~V}_{\mathrm{P}}+30.631$ & 0.70 & $\mathrm{~T}$ \\
\hline
\end{tabular}

simple regression analysis and confidence interval; and Fig. $6 \mathrm{c}$ illustrates data plotted showing linear nature of the relationship (in the form $y=a x+b$ with $R^{2} 0.64$ ). The confidence intervals were set at $95 \%$. The range of slake durability values found from graph is $93.1-99.6 \%$ and $V p$ range is $2-5 \mathrm{~km} / \mathrm{s}$. From the plotted graph, it is observed that slake durability increases with an increase in Vp. [66] found a linear correlation between Vp and SDI, with a regression coefficient of 0.903. [70] also reported a similar linear correlation, but they found low correlation coefficient 0.7831 . Table 13 presents the summary of correlation 
laws between ultrasonic velocity $(\mathrm{Vp})$ and $\mathrm{SDI}$ as proposed by researchers.

The other parameter, i.e. point load strength, is also a measure for the determination of rock strength. The combined graphical representation of change of point load strength with $\mathrm{Vp}$ is presented in Fig. 7, where Fig. 7a illustrates data as reported by different researchers; Fig. $7 \mathrm{~b}$ illustrates data including general trend derived from this study using simple regression analysis and confidence interval; and Fig. 7c illustrates data plotted on a log-log scale (since a reasonable straight line is obtained on doing so), indicating nonlinear nature relationship (of the form $y=a x^{b}$, with $R^{2}=0.59$ ). The confidence intervals were set at $95 \%$. Table 14 presents the summary of different correlations between ultrasonic velocity $(\mathrm{Vp})$ and point load strength, along with $V p-V s, V p$-shear strength and $\mathrm{Vp}-\mathrm{V}$ (loss of volume on wear, $\mathrm{cm}^{3} / 50 \mathrm{~cm}^{2}$ ) as proposed by researchers. The range of point load strength values found from graph is $0.35-8.6 \mathrm{MPa}$ and $\mathrm{Vp}$ range is $1.47-6.75 \mathrm{~km} / \mathrm{s}$. From the plotted graph, it is noted that point load strength increases proportionately with Vp.

Several theoretical velocity models were reported in the literature $[1,45]$ to predict $\mathrm{Vp}$. [45] in their study reported that for rocks with high effective clay content, the utilisation of theoretical velocities is not favourable since the comparison between theoretical Gassmann-Biot velocities and experimental results showed inconsistency when calculated at varying degrees of saturation. Similarly, [1] reported that, for low-porosity rocks, the theoretical velocities (predicted by both Gassmann and Biot theories) overestimated the measured velocities, due to the negligence of rock-fluid interaction. Also, when compared to Biot-Gassmann velocity model, time average and Raymer's relationships overestimated Vp [1]. Thus, it can be concluded that the use of theoretical models may yield over or under predictions.

In general, the properties of the dataset obtained from the literature cover a wide range of exploration interests. The statistical summary of different geotechnical properties (UCS, indirect tensile strength, $E$, $U$, slake durability, point load strength) and their corresponding Vp obtained from the literature is presented in Table 15. Studies related to improving the fracturing index-based brittleness prediction [84] and $V$ s estimation by combining classification and regression methods [17] may help to build a more realistic model.

\section{Critical Summary and Conclusion}

The study presents a comprehensive review of all the correlations and relationships that exist between several geomechanical properties of sedimentary rocks with the ultrasonic velocity. Based on the comprehensive scrutiny from the available literature, it can be concluded that it is extremely important to focus the research towards an inclusive study incorporating the petrophysical, geological and mechanical factors so as to identify and address all the scenarios that lead to an alteration in the geomechanical and elastic properties of rocks. Past reviews provide a good understanding and development related to the relationships that exist between several geomechanical properties and Vp. Seismic measurements can be utilised to provide a direct evaluation of the nature of rock mass (indicator
Table 15 Statistical summary of different geotechnical properties and their corresponding $\mathrm{V}_{\mathrm{p}}$ obtained from the literature

\begin{tabular}{|c|c|c|c|c|}
\hline \multirow[t]{3}{*}{ Point load strength (MPa) } & Mean \pm SD & $2.69 \pm 1.46$ & $\mathrm{Vp}(\mathrm{km} / \mathrm{s})$ & $4.34 \pm 1.11$ \\
\hline & Minimum & 0.35 & & 1.47 \\
\hline & Maximum & 8.6 & & 6.75 \\
\hline \multirow[t]{3}{*}{ Slake durability (\%) } & Mean \pm SD & $97.17 \pm 2.02$ & $\mathrm{Vp}(\mathrm{km} / \mathrm{s})$ & $3.16 \pm 0.99$ \\
\hline & Minimum & 93.1 & & 2 \\
\hline & Maximum & 99.6 & & 5 \\
\hline \multirow[t]{3}{*}{ Poisson's ratio } & Mean \pm SD & $0.34 \pm 0.038$ & $\mathrm{Vp}(\mathrm{km} / \mathrm{s})$ & $4.36 \pm 0.86$ \\
\hline & Minimum & 0.23 & & 2.204 \\
\hline & Maximum & 0.4 & & 5.8 \\
\hline \multirow[t]{3}{*}{ Young's modulus (GPa) } & Mean $\pm S D$ & $33.94 \pm 24.48$ & $\mathrm{Vp}(\mathrm{km} / \mathrm{s})$ & $4.35 \pm 1.09$ \\
\hline & Minimum & 2 & & 1.47 \\
\hline & Maximum & 69.14 & & 6.75 \\
\hline \multirow[t]{3}{*}{ Tensile strength (MPa) } & Mean \pm SD & $6.23 \pm 3.75$ & $\mathrm{Vp}(\mathrm{km} / \mathrm{s})$ & $4.53 \pm 1.09$ \\
\hline & Minimum & 0.7 & & 1.47 \\
\hline & Maximum & 19.7 & & 6.75 \\
\hline \multirow[t]{3}{*}{ UCS (MPa) } & Mean \pm SD & $54.45 \pm 31.67$ & $\mathrm{Vp}(\mathrm{km} / \mathrm{s})$ & $4.36 \pm 1.16$ \\
\hline & Minimum & 10 & & 2 \\
\hline & Maximum & 145 & & 6.5 \\
\hline
\end{tabular}


of geomechanical behaviour). With the use of this geophysical technique, information related to exploration studies can be increased since rock types can be assessed qualitatively. However, it is important to mention that it is unlikely that these measurements would ever replace the mechanically derived geomechanical tests, although a variation can be estimated. Nevertheless, following salient points can be summarised after the critical scrutiny of the literature:

- It is evident from the literature that there exists a definite link between $V p$, Vs with mechanical properties of rocks, and hence, it can be considered as a dependable parameter to provide a link with these properties. It is observed that UCS, Brazilian tensile strength, point load index and $E$ increase with an increase in $\mathrm{Vp}$, but $v$ decreases. Moreover, a number of rock strength correlations have been summarised which may be useful in geotechnical applications (design and planning for use in general practice with greater safety and stability) by providing lower bound strength estimate when no other information is available, thus saving time and cost in performing tedious and rigorous test methods. These relations will also be helpful where no prior knowledge on rock strength is available or in situations where there is an absence of rock cores for performing laboratory tests in situ rocks. However, measurement of $V p$ can be viewed as complementary and cannot simply replace the mechanical testing of rock specimens under certain testing procedures. Nevertheless, the correlation listed in this review study may be generalised for almost all types of rock and help to identify the different alterations in rock mass strength.

- Development of empirical and/or semi-analytical equations/models needs attention. The empirical relations established in the literature are mere site specific (lack generalisation) and may lead to mis-classification. The datasets exhibit wide ranges for velocities and geomechanical parameters. This is because there are several other parameters such as mineralogy, pore geometry, rock framework, saturation and porosity that influence these geomechanical properties. Furthermore, several trends of geomechanical parameters conclude that there is an undercovered trend that affects these parameters and a combined analysis involving the integration of geological, petrophysical and engineering properties (geomechanical properties) is required to understand this undercovered trend. In order to widen the acceptability of these empirical equations and to improve the existing ones, the influential parameters such as degree of saturation, effective clay content, the rock's composition (matrix), mineral constituents and void space (pore geometry/pore structure/pore archi- tecture/pore size distribution) of the rock also need to be taken into account. All these petrophysical parameters including the difference in depositional environments, composition, degree of weathering, texture and complex diagenesis processes influence the internal structure of the rock, and neglecting these parameters would result in an under or overestimated predictions. Such studies should be undertaken in future research so as to understand the effects which would be favourable in interpreting the overall picture. An attempt is made in this study to understand the variability of $\mathrm{Vp}$ with the help of a fragmented analysis of major mineral constituents, porosity variation and saturation conditions for rock mass classification. The resulting template so generated may provide a basis for interpreting lithology, thereby favourable in facilitating more realistic geomechanical behaviours of rocks (rock mass performance).

- The modulus obtained from ultrasonic testing only provides the modulus in the very low strain elastic range (dynamic modulus), whereas for most design purposes, modulus values are from much higher strains (static modulus) often with strain of a per cent or more. The method of testing can also have a significant effect depending on whether strain is measured over the length and diameter of the sample or from local strain gauges such as direct contact strain gauges. The static modulus is generally lesser than the dynamic modulus, and the literature establishing the correlations between the static and dynamic moduli of various varieties of rock is available.

Extensive combined analysis involving the integration of geological, petrophysical and engineering properties (mechanical properties) is presently scarce. Much attention is required to further understand and develop standard guidelines/predictions for field experimentation so as to reinforce the technique as an equally important, complementary technique.

\section{Compliance with ethical standards}

Conflict of interest The authors declare that they have no conflict of interest.

\section{References}

1. Assefa S, Mccann C, Sothcott J (2003) Velocities of compressional and shear waves in limestones. Geophys Prospect 51:1-13

2. ASTM D 2845-08 (2005) Standard test method for laboratory determination of pulse velocities and ultrasonic elastic constants of rock 
3. ASTM D 5731-08 (2008) Standard test method for determination of the point load strength index of rock and application to rock strength classifications

4. ASTM D 7012-10 (2010) Standard test method for compressive strength and elastic moduli of intact rock core specimens under varying states of stress and temperatures

5. Berryman JG (1995) Mixture theories for rock properties. Rock Phys Phase Relat: A Handb Phys Const 3:205-228

6. Brocher TM (2005) Empirical relations between elastic wavespeeds and density in the Earth's crust. Bull Seismol Soc Am 95(6):2081-2092

7. Brotons V, Tomas R, Ivorra S, Grediaga A, Martınez J, Benavente D, Gomez M (2016) Improved correlation between the static and dynamic elastic modulus of different types of rocks. Mater Struct 49:3021-3037

8. Burchette TP (2012) Carbonate rocks and petroleum reservoirs: a geological perspective from the industry. In: Advances in carbonate exploration and reservoir analysis, vol 370, no 1. Geological Society, London, Special Publications, pp 17-37

9. Castagna P, Batzle ML, Eastwood RL (1985) Relationships between compressional-wave and shear-wave velocities in clastic silicate rocks. Geophysics 50(4):571-581

10. Chaki S, Takarli M, Agbodjan WP (2008) Influence of thermal damage on physical properties of a granite rock: porosity, permeability and ultrasonic wave evolutions. Constr Build Mater 22:1456-1461

11. Chang C, Zoback MD, Khaksar A (2006) Empirical relations between rock strength and physical properties in sedimentary rocks. J Petrol Sci Eng 51:223-237

12. Chen X, Xu Z (2017) The ultrasonic P-wave velocity-stress relationship of rocks and its application. Bull Eng Geol Env 76(2):661-669

13. Choquette PW, Pray LC (1970) Geologic nomenclature and classification of porosity in sedimentary carbonates. AAPG Bull 54(2):207-250

14. Çobanoğlu İ, Çelik SB (2008) Estimation of uniaxial compressive strength from point load strength, Schmidt hardness and P-wave velocity. Bull Eng Geol Environ 67(4):491-498

15. D'Andrea DV, Fischer RL, Fogelson DE (1965) Prediction of compressive strength from other rock properties, vol 6702. US Department of the Interior, Bureau of Mines

16. Domenico SN (1984) Rock lithology and porosity determination from shear and compressional wave velocity. Geophysics 49(8):1188-1195

17. Du Q, Yasin Q, Ismail A, Sohail GM (2019) Combining classification and regression for improving shear wave velocity estimation from well logs data. J Petrol Sci Eng 182:106260

18. Dunn ML, Ledbetter H (1995) Poisson's ratio of porous and microcracked solids: theory and application to oxide superconductors. J Mater Res 10(11):2715-2722

19. Ehrenberg SN, Nadeau PH (2005) Sandstone vs. carbonate petroleum reservoirs: a global perspective on porosity-depth and porosity-permeability relationships. AAPG Bull 89(4):435-445

20. Entwisle DC, Hobbs PRN, Jones LD, Gunn D, Raines MG (2005) The relationships between effective porosity, uniaxial compressive strength and sonic velocity of intact Borrowdale Volcanic Group core samples from Sellafield. Geotech Geol Eng 23:793-809

21. Fereidooni $D$ (2018) Assessing the effects of mineral content and porosity on ultrasonic wave velocity. Geomech Eng 14(4):399-406

22. Fjaer E (1999) Static and dynamic moduli of weak sandstone. Rock Mechanics for Industry, Balkema, pp 675-681

23. Freyburg E (1972) Der Untere und mittlere Buntsandstein SWThuringen in seinen gesteinstechnicschen Eigenschaften.
Deustche Gesellschaft Geologische Wissenschaften A; Berlin 176:911-919

24. Gaviglio P (1989) Longitudinal waves propagation in a limestone: the relationship between velocity and density. Rock Mech Rock Eng 22(4):29-306

25. Gegenhuber N (2016) Interpretation of elastic properties for magmatic and metamorphic rock types. Int J Rock Mech Min Sci 88:44-48

26. Gercek HA (2007) Poisson's ratio values for rocks. Int J Rock Mech Min Sci 44:1-13

27. Ghafoori M, Rastegarnia A, Lashkaripour GR (2018) Estimation of static parameters based on dynamical and physical properties in limestone rocks. J Afr Earth Sc 137:22-31

28. Han D, Nur A, Morgan D (1986) Effects of porosity and clay content on wave velocities in sandstones. Geophysics 51:2093-2107

29. ISRM, Suggested Method for determining point load strength, Int. J. Rock Mech. Min. Sci. 22 (1985) 53-60

30. ISRM (1978) Suggested method for determining sound velocity. Int J Rock Mech Min Sci Geomech Abstr 15:53-58

31. ISRM (1978) Suggested Method for determining uniaxial compressive strength and deformability of rock materials. Int J Rock Mech Min Sci Geomech 16:135-140

32. ISRM (1977) Suggested methods for determining water content, porosity, density, absorption and related properties and swelling and slake-durability index properties. Int J Rock Mech Min Sci Geomech Abstr 16:141-156

33. Ji S (2004) A generalized mixture rule for estimating the viscosity of solid-liquid suspensions and mechanical properties of polyphase rocks and composite materials. J Geophys Res: Solid Earth 109:B10207

34. Ji S, Gu Q, Xia B (2006) Porosity dependence of mechanical properties of solid materials. J Mater Sci 41(6):1757-1768

35. Ji S, Li L, Motra HB, Wuttke F, Sun S, Michibayashi K, Salisbury MH (2018) Poisson's ratio and auxetic properties of natural rocks. J Geophys Res: Solid Earth 123(2):1161-1185

36. Ji S, Sun S, Wang Q, Marcotte D (2010) Lamé parameters of common rocks in the Earth's crust and upper mantle. J Geophys Res: Solid Earth 115:B06314

37. Ji S, Wang Q, Xia B (2003) P-wave velocities of polymineralic rocks: comparison of theory and experiment and test of elastic mixture rules. Tectonophysics 366(3-4):165-185

38. Ji S, Wang Q, Marcotte D, Salisbury MH, Xu Z (2007) P wave velocities, anisotropy and hysteresis in ultrahigh-pressure metamorphic rocks as a function of confining pressure. J Geophys Res: Solid Earth 112:B09204

39. Ji S, Wang Q, Xia B, Marcotte D (2004) Mechanical properties of multiphase materials and rocks: a phenomenological approach using generalized means. J Struct Geol 26(8):1377-1390

40. Johnston DH, Toksoz MN (1980) Ultrasonic $P$ and $S$ wave attenuation in dry and saturated rocks under pressure. J Geophys Res 85(9):925-936

41. Johnston JE, Christensen NI (1993) Compressional to shear velocity ratios in sedimentary rocks. Int J Rock Mech Min Sci Geomech Abstr 30(7):751-754

42. Kahraman S (2001) A correlation between P-wave velocity, number of joints and Schmidt hammer rebound number. Int J Rock Mech Min Sci 38(5):729-733

43. Kahraman $S$ (2007) The correlations between the saturated and dry P-wave velocity of rocks. Ultrasonics 46(4):341-348

44. Kahraman S, Yeken T (2008) Determination of physical properties of carbonate rocks from P-wave velocity. Bull Eng Geol Environ 67:277-281

45. Karakul H, Ulusay R (2013) Empirical correlations for predicting strength properties of rocks from P-wave velocity under different degrees of saturation. Rock Mech Rock Eng 46:981-999 
46. Kassab MA, Weller A (2015) Study on P-wave and S-wave velocity in dry and wet sandstones of Tushka region, Egypt. Egypt J Petrol 24(1):1-11

47. Khandelwal M, Ranjith PG (2010) Correlating index properties of rocks with P-wave measurements. J Appl Geophys 71(1):1-5

48. Kilic A, Teymen A (2008) Determination of mechanical properties of rocks using simple methods. Bull Eng Geol Envirol 67(2):237-244

49. King MS (1970) Static and dynamic moduli of rocks under pressure. In: Somerton WH (ed) Proceedings of the 11th symposium on rock mechanics, California. American Institute of Mining Engineers, New York, pp 329-351

50. Klimentos T (1991) The effects of porosity-permeability-clay content on the velocity of compressional waves. Geophysics 56:1930-1939

51. Kurtulus C, Cakir S, Yogurtcuoglu AC (2016) Ultrasound study of limestone rock physical and mechanical properties. Soil Mech Found Eng 52(6):27-31

52. Madhubabu N, Singh PK, Kainthola A, Mahanta B, Tripathy A, Singh TN (2016) Prediction of compressive strength and elastic modulus of carbonate rocks. Measurement 88:202-213

53. Mavko G, Mukerji T, Dvorkin J (2009) The rock physics handbook: Tools for seismic analysis of porous media. Cambridge University Press, Cambridge

54. McCann DM, Culshaw MG, Northmore KJ (1990) Rock mass assessment from seismic measurements. Geol Soc Lond Eng Geol Spec Publ 6(1):257-266

55. McDowell PW, Millett N (1984) Surface ultrasonic measurement of longitudinal and transverse wave velocities through rock samples. Int J Rock Mech Min Sci Geomech Abstr 21:223-227

56. Moore $\mathrm{CH}$, Wade WJ (2013) Carbonate reservoirs: Porosity and diagenesis in a sequence stratigraphic framework. Newnes, Boston

57. Moos AV, De Quervain F (1948) Technishe Gesteinkunde. Verlag Birkhauser, Basel (in German)

58. Moos D, Zoback MD, Bailey L (2001) Feasibility study of the stability of openhole multilaterals, Cook Inlet, Alaska. SPE Drill Compl 16(03):140-145

59. Moradian ZA, Behnia M (2009) Predicting the uniaxial compressive strength and static young's modulus of intact sedimentary rocks using the ultrasonic test. Int J Geomech 9(1):14

60. Mueller HJ (2013) Measuring the elastic properties of natural rocks and mineral assemblages under Earth's deep crustal and mantle conditions. J Geodyn 71:25-42

61. Nefeslioglu HA (2013) Evaluation of geo-mechanical properties of very weak and weak rock materials by using non-destructive techniques: ultrasonic pulse velocity measurements and reflectance spectroscopy. Eng Geol 160:8-20

62. Nur A, Simmons G (1969) Stress-induced velocity anisotropy in rock: an experimental study. J Geophys Res 74(27):6667-6674

63. Pappalardo G (2015) Correlation between P-wave velocity and physical-mechanical properties of intensely jointed Dolostones, Peloritani Mounts, NE Sicily. Rock Mech Rock Eng 48:1711-1721

64. Parent T, Domede N, Sellier A, Mouatt L (2015) Mechanical characterization of limestone from sound velocity measurement. Int J Rock Mech Min Sci 79:149-156

65. Perras MA, Diederichs MS (2014) A review of the tensile strength of rock: concepts and testing. Geotech Geol Eng 32(2):525-546

66. Sarkar K, Vishal V, Singh TN (2012) An empirical correlation of index geomechanical parameters with the compressional wave velocity. Geotech Geol Eng 30:469-479
67. Sayers CM (2008) The elastic properties of carbonates. Lead Edge 27(8):1020-1024

68. Schön JH (2015) Physical properties of rocks: Fundamentals and principles of petrophysics, vol 65. Elsevier, Amsterdam

69. Shahri AA, Gheirati A, Espersson M (2014) Prediction of rock mechanical parameters as a function of P-wave velocity. Int Res J Earth Sci 2(9):7-14

70. Sharma PK, Singh TN (2008) A correlation between P-wave velocity, impact strength index, slake durability index and uniaxial compressive strength, Bull Eng. Geol. Envirol 67:17-22

71. Simmons $G$ (1965) Single crystal elastic constants and calculated aggregate properties. Southern Methodist Univ Dallas Tex

72. Singh TN, Verma AK, Singh V, Sahu A (2005) Slake durability study of shaly rock and its predictions. Environ Geol 47(2):246-253

73. Soroush H, Qutob H, Oil W, Me T (2011) Evaluation of rock properties using ultrasonic pulse technique and correlating static to dynamic elastic constants. In: 2nd South Asian geoscience conference and exhibition, GEOIndia 2011, Greater Noida, New Delhi, India

74. Toksoz MN, Cheng CH, Timur A (1976) Velocities of seismic waves in porous rocks. Geophysics 41:621-645

75. Vernik L, Bruno M, Bovberg C (1993) Empirical relations between compressive strength and porosity of siliciclastic rocks. Int J Rock Mech Min Sci Geomech Abstr 30(7):677-680

76. Vilhelm J, Ivankina T, Lokají T, Rudajev V (2016) Comparison of laboratory and field measurements of $\mathrm{P}$ and $\mathrm{S}$ wave velocities of a peridotite rock. Int J Rock Mech Min Sci 88:235-241

77. Walpole LJ (1966) On bounds for the overall elastic moduli of inhomogeneous systems-I. J Mech Phys Solids 14(3):151-162

78. Wang Q, Ji S (2009) Poisson's ratios of crystalline rocks as a function of hydrostatic confining pressure. J Geophys Res: Solid Earth 114(B9)

79. Wang Q, Ji S, Sun S, Marcotte D (2009) Correlations between compressional and shear wave velocities and corresponding Poisson's ratios for some common rocks and sulfide ores. Tectonophysics 469(1-4):61-72

80. Wen L, Quan Luo Z, Jiao Yang S, Guang Qin Y, Wang W (2019) Correlation of geo-mechanics parameters with uniaxial compressive strength and P-wave velocity on dolomitic limestone using a statistical method. Geotech Geol Eng 37(2):1079-1094

81. Yagiz S (2011) P-wave velocity test for assessment of geotechnical properties of some rock materials. Bull Mater Sci 34(4):947

82. Yale DP, Jamieson WH (1994) Static and dynamic mechanical properties of carbonates, American Rock Mechanics Association

83. Yasar E, Erdogan Y (2004) Correlating sound velocity with the density, compressive strength and Young's modulus of carbonate rocks. Int J Rock Mech Min Sci 41(2004):871-875

84. Yasin Q, Du Q, Sohail GM, Ismail A (2018) Fracturing index-based brittleness prediction from geophysical logging data: application to Longmaxi shale. Geomech Geophys Geo-Energy GeoResour 4(4):301-325

85. Yu C, Ji S, Li Q (2016) Effects of porosity on seismic velocities, elastic moduli and Poisson's ratios of solid materials and rocks. J Rock Mech Geotech Eng 8(1):35-49

Publisher's Note Springer Nature remains neutral with regard to jurisdictional claims in published maps and institutional affiliations. 